\title{
Natural Variation in Plant Pluripotency and Regeneration
}

\author{
Robin Lardon $(\mathbb{D}$ and Danny Geelen * \\ Department of Plants and Crops, Horticell, Ghent University, 9000 Gent, Belgium; robin.lardon@ugent.be \\ * Correspondence: danny.geelen@ugent.be; Tel.: +32-9-264-60-76
}

Received: 6 August 2020; Accepted: 21 September 2020; Published: 24 September 2020

check for updates

\begin{abstract}
Plant regeneration is essential for survival upon wounding and is, hence, considered to be a strong natural selective trait. The capacity of plant tissues to regenerate in vitro, however, varies substantially between and within species and depends on the applied incubation conditions. Insight into the genetic factors underlying this variation may help to improve numerous biotechnological applications that exploit in vitro regeneration. Here, we review the state of the art on the molecular framework of de novo shoot organogenesis from root explants in Arabidopsis, which is a complex process controlled by multiple quantitative trait loci of various effect sizes. Two types of factors are distinguished that contribute to natural regenerative variation: master regulators that are conserved in all experimental systems (e.g., WUSCHEL and related homeobox genes) and conditional regulators whose relative role depends on the explant and the incubation settings. We further elaborate on epigenetic variation and protocol variables that likely contribute to differential explant responsivity within species and conclude that in vitro shoot organogenesis occurs at the intersection between (epi) genetics, endogenous hormone levels, and environmental influences.
\end{abstract}

Keywords: callus formation; de novo organogenesis; epigenetics; mapping; natural variation; plant regeneration; pluripotency; quantitative trait loci; tissue culture

\section{Introduction: Definition, Origin, and Applications of Regeneration}

As sessile organisms, plants face numerous environmental stresses, and, accordingly, they have retained extended developmental plasticity compared to animals [1]. This ability to redirect the fate of differentiated somatic cells potentiates tissue repair and organ reconstruction after injury during postembryonic growth and de novo formation of various plant structures from in vitro explant cultures upon exposure to phytohormones or abiotic stresses, which is collectively termed regeneration and has contributed to several biotechnological applications [2,3]. For instance, various ornamentals are produced by micropropagation, in which excised tissues are cultured on growth media supplemented with plant hormones to regenerate whole plantlets that can be transferred to soil. This ability to recreate the entire body from a few cells, or even a single cell, is commonly known as totipotency, and it was first postulated by Haberlandt in 1902, although it was not until 1957, when Skoog and Miller discovered that the ratio of auxin and cytokinin in the culture medium determines the identity of newly formed organs, that the first regeneration protocols were established [4]. The advantages of the approach include a large propagation factor, while the fixation of strong genotypes because of asexual reproduction and extensive control over the culture conditions ensures high-yielding phenotypes [5]. On the other hand, genetic homogeneity should be carefully monitored to avoid somaclonal variations that might arise during subculture, unless these are desirable for selection purposes [6]. Other applications are virus sanitization and the development of transgenic crops, which requires regeneration from tissues or protoplasts transformed with a particular genetic construct. When applied to pollen, this leads to the creation of haploid plants that can be chemically converted to homozygous individuals for use in crop 
breeding [7,8]. Most differentiated tissues, however, are limited to pluripotency, i.e., the reconstruction of specific cell types. This is exploited in techniques such as cutting and grafting, allowing the reuse of resilient root stocks with high-yielding scions. The success of these approaches is highly variable between species, cultivars, and even explants of the same individual and we are only beginning to understand the sources of such variation. This review summarizes various regeneration systems, along with recent advances in our understanding of the molecular framework underlying de novo shoot organogenesis in Arabidopsis thaliana. Based on that knowledge, we attempt to bridge the gap between reports on organogenic variability between and within different species and natural variation in several regulatory layers of regeneration.

\section{Different Regeneration Systems}

While simple organisms such as liverworts and mosses are able to reconstruct their full body without additional hormonal signals after injury [9], regeneration in seed plants involves a complex interplay of multiple inductive cues to repair cuts or recreate organs [10]. Cereals and woody species often show recalcitrance to tissue cultivation and micropropagation due to restricted availability or accessibility of pluripotent stem cells [7]. Three key systems have been used to study and exploit plant regeneration in Arabidopsis thaliana (Figure 1) [1,2]. The first is based on an extensive capacity for wound repair and organ reconstruction that allows for root tip regeneration after laser ablation of the quiescent center (QC) or excision of the root apical meristem (RAM), the repair of stem tissues after incision and reconnection of the vasculature of stock and scion during grafting, all relying on populations of competent cells in the adult plant body and polar auxin transport [2,10]. Besides tissue repair, the two most common types of regeneration in higher plants are somatic embryogenesis and de novo organogenesis, which can both occur in a direct or indirect way depending on the requirement for an intermediate callus stage (Figure 1) [1,11]. Somatic embryogenesis reinitiates embryonic developmental sequences in (de)differentiated cells to generate bipolar structures with a clear distinction between root and shoot meristems $[1,2,8,12]$. This can be induced by abiotic stresses such as salt, heavy metals, heat, and drought $[13,14]$, but it is usually achieved by treatment with the synthetic auxin 2,4-dichlorophenoxyacetic acid (2,4-D) via the formation of embryogenic callus [8,12]. The subsequent transfer of explants to hormone-free medium initiates somatic embryogenesis, creating cellular structures reminiscent of globular, heart-shaped, and torpedo-shaped embryogenic stages through the coordinated action of transcription factors (TFs) such as LEAFY COTYLEDON (LEC) 1 and 2, AGAMOUS-LIKE 15 (AGL15), FUSCA 3 (FUS3), BABYBOOM (BBM), and EMBRYOMAKER (EMK) $[5,8,12]$. De novo organogenesis, on the other hand, refers to the formation of new meristems from pluripotent stem cells to reconstruct organs [2]. Typical examples include adventitious rooting from detached leaves, petioles, or hypocotyls (also termed rhizogenesis) and shoot regeneration from in vitro cultured root or hypocotyl segments (sometimes referred to as caulogenesis) [10]. The outcome of both processes is governed by the plant hormones auxin and cytokinin as a high auxin ratio favors root growth, while high cytokinin content promotes shoot fate [4]. De novo root regeneration has been exploited for vegetative propagation through cuttings and can be achieved by cultivation on auxin-rich callus-inducing medium (CIM), followed by transfer to root induction medium (RIM) with less or no auxin $[2,10]$. More recent systems dispense with external hormone supply, resulting in direct root regeneration governed by wounding, endogenous hormone levels, and a transcriptional cascade involving WUSCHEL-RELATED HOMEOBOX (WOX) 11 and 12, WOX5E7, and LATERAL ORGAN BOUNDARIES DOMAIN (LBD) 16 and 29 [15-17]. Similarly, the two-step protocol for de novo shoot organogenesis, in which explants are preincubated on auxin-rich CIM before transfer to shoot induction medium (SIM) with high cytokinin levels, constitutes a vital step in many transformation protocols $[4,10,18]$. Aside from hormone signaling, shoot regeneration involves wound responses for callus formation from founder cells and acquisition of organogenic competence, followed by transdifferentiation of root-like protuberances into shoot primordia, patterning of the 
shoot apical meristem (SAM), and subsequent organ outgrowth [4,7,19-22]. Cellular and molecular events underlying these stages are discussed in the next section.

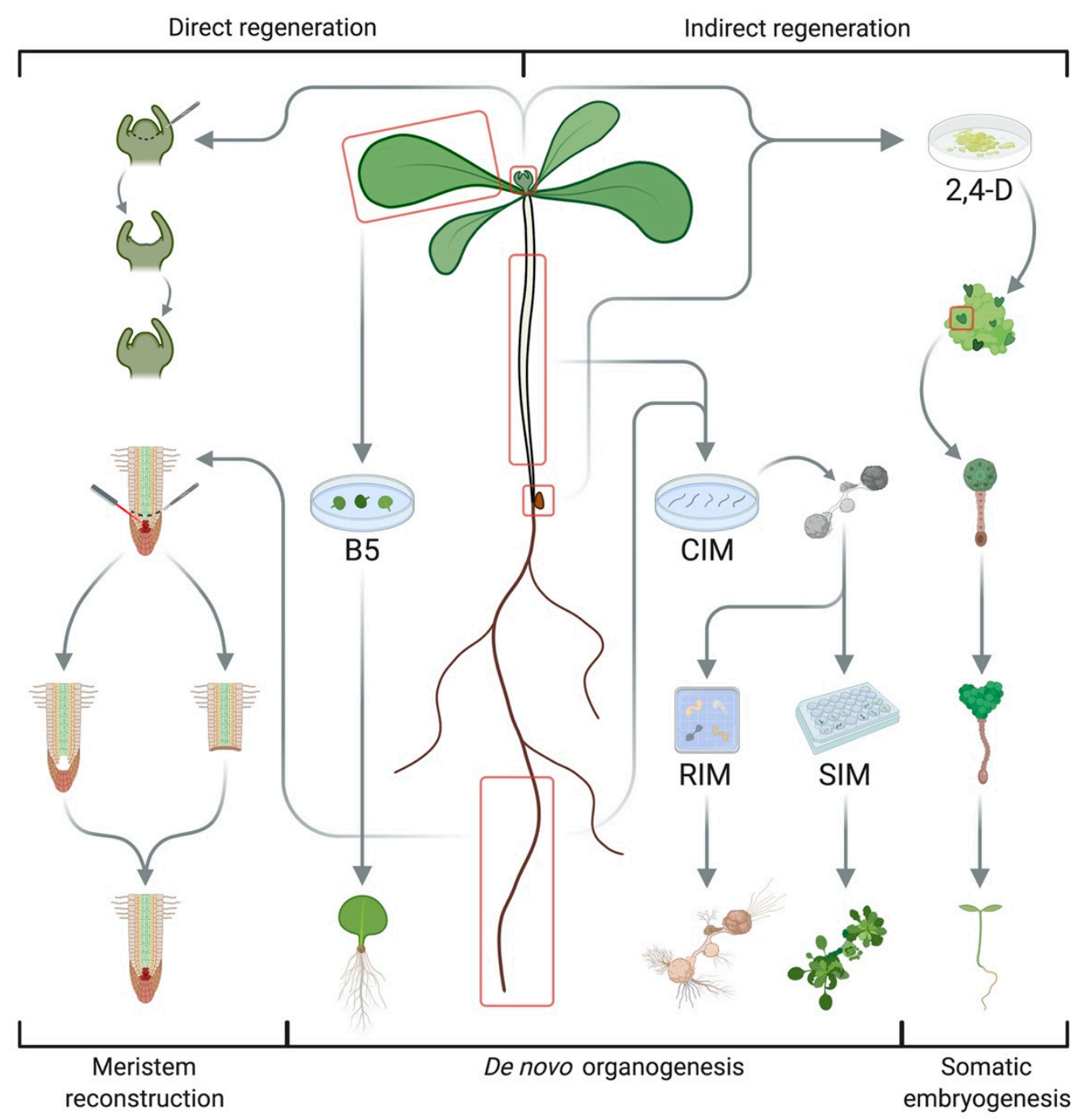

Figure 1. Diagram of key regeneration systems in Arabidopsis thaliana, including the reconstruction of shoot or root apical meristems after excision or laser ablation, adventitious rooting from excised leaves or cotyledons, de novo shoot or root organogenesis from root or hypocotyl explants, and somatic embryogenesis from immature zygotic embryos or shoot apices. This illustration was created with BioRender.com.

\section{Cellular and Molecular Framework of de novo Shoot Organogenesis}

\subsection{Auxin and Cytokinin Signalling}

Auxin and cytokinin play vital, but often antagonistic roles in de novo shoot formation and mutations in the homeostatic or signaling pathway of either hormone are known to impair regeneration $[4,23]$. Auxin is synthesized from tryptophan (Trp) in a two-step reaction orchestrated by TRYPTOPHAN AMINOTRANSFERASE (TAA) and YUCCA (YUC) enzymes, and its perception involves an SKP1-cullin-F-box (SCF)-type E3 ubiquitin ligase, in which an F-box protein from the TRANSPORT INHIBITOR RESISTANT 1 (TIR1)/AUXIN SIGNALING F-BOX (AFB) family provides substrate specificity [24]. In the presence of auxin, this $S C F^{\mathrm{TIR} 1 / A F B 1-5}$ coreceptor complex binds Aux/IAA (INDOLE-3-ACETIC ACID INDUCIBLE) repressor proteins and targets them for proteasomal degradation, which releases TOPLESS (TPL)-mediated repression of AUXIN RESPONSE 
FACTORs (ARFs) that induce auxin-responsive gene expression. Cytokinins, on the other hand, are synthesized from adenosine triphosphate (ATP) or diphosphate (ADP) in two successive reactions, respectively catalyzed by ISOPENTENYLTRANSFERASE (IPT) and LONELEY GUY (LOG) enzymes [24]. Active hormone levels are also regulated by conjugation and irreversible degradation, mainly by cytokinin oxidases or dehydrogenases (CKX) [4]. Cytokinin is perceived by a multicomponent His-to-Asp phosphorelay, starting at one of three hybrid ARABIDOPSIS HISTIDINE KINASEs (AHKs) that autophosphorylate upon cytokinin binding and transfer the $P_{i}$ to ARABIDOPSIS HISTIDINE PHOSPHOTRANSFER PROTEINs (AHPs). The latter act as shuttle proteins, conveying the signal into the nucleus, where they activate two types of ARABIDOPSIS RESPONSE REGULATORS (ARRs): type-B ARRs that act as transcriptional activators of the cytokinin response, and type-A ARRs that form a negative feedback loop on the signal [4]. Auxin and cytokinin show extensive crosstalk during shoot regeneration, exemplified by reciprocal control over each other's biosynthesis $[25,26]$. Ethylene (ET), brassinosteroids (BR), gibberellin (GA), and abscisic acid (ABA) interfere in the process as well [19,23].

\subsection{Wound Responses}

Intact seedlings subjected to the CIM-SIM procedure regenerate lateral roots instead of shoots, indicating the importance of wound stress for de novo SAM formation [27]. Moreover, new organs are often formed naturally at cut sites, and wounding enhances several types of hormone-induced regeneration, including somatic embryogenesis $[7,10]$. Early wound responses involve rapid $\mathrm{Ca}^{2+}$ influxes, plasma membrane depolarization, a burst of reactive oxygen species (ROS), disruption of cellular communication, and jasmonic acid (JA) accumulation, although it is not well understood how these are translated into waves of extensive transcriptional changes observed after wounding $[7,28]$. Central regulators of wound-induced reprogramming are the APETHALA2/ETHYLENE RESPONSE FACTOR (AP2/ERF) TF WOUND-INDUCED DEDIFFERENTIATION 1 (WIND1) and its homologs WIND2-4, which are expressed locally within $1 \mathrm{~h}$ after wounding and promote cell dedifferentiation and proliferation $[29,30]$. Recently, it was reported that WIND1 acts by promoting cytokinin signaling through B-type ARRs and directly activating ENHANCER OF SHOOT REGENERATION 1 (ESR1) to upregulate CUP-SHAPED COTYLEDON 1 (CUC1), an important determinant of SAM formation during embryogenesis [31]. Moreover, induction of IPT3 and LOG1, LOG4, and LOG5 upon cutting elevates cytokinin levels, in turn reactivating the cell cycle via CYCLIN D3;1 (CYCD3;1) [7]. Other AP2/ERFs, such as ERF115 and PLETHORA (PLT) 3, -5, and -7, are also expressed during wound-induced callus formation, and the AP2/ERF and CK-mediated pathways undergo extensive crosstalk [28]. Many chromatin remodeling factors, including POLYCOMB REPRESSIVE COMPLEX 2 (PRC2) components and DNA methyltransferases MET1 and CHROMOMETHYLASE 2 (CMT2), are differentially regulated by cutting as well. Accordingly, it was shown that chromatin modifications undergo dynamic changes upon wounding and accumulation or loss of histone 3 lysine 4 trimethylation (H3K4me3), and lysine 9/14/27 acetylation (H3K9/14/27ac), dependent on HISTONE ACETYLTRANSFERASE OF THE GNAT FAMILY 1 and 3 (HAG1\&3), is respectively correlated to transcriptional activation or repression [32]. Genes with high levels of these permissive histone marks before or shortly after wounding (such as WIND1, ERF113/RAP2.6L, and LBD16) tend to be rapidly induced by cutting, whereas genes with $\mathrm{H} 3 \mathrm{~K} 36 \mathrm{me} 3$ and $\mathrm{H} 3 \mathrm{~K} 27 \mathrm{me} 3$ are less responsive to wounding. Notably, it has been suggested that wound-induced calli differ from calli formed on CIM because the former do not express root markers and their induction is not affected in solitary root (slr) mutants $[29,33,34]$.

\subsection{Founder Cell Specification}

When explants are placed on CIM, the high auxin concentration triggers cell division to initiate the formation of a proliferating cell mass or callus $[4,35]$. While it was first thought that any somatic cell can dedifferentiate and reenter the cell cycle, this ability is, in fact, restricted to populations of partially differentiated stem cells distributed throughout the adult plant body [11]. In the case of shoot 
regeneration from root explants, pluripotent pericycle cells, opposite of the xylem poles, are required for callus formation $[35,36]$. Similar to lateral root initiation, founder cells are specified by local auxin maxima instated by the AUXIN RESISTANT 1 (AUX1) and AUX1-LIKE (LAX) 1-3 influx carriers [4]. Use of the synthetic auxins 2,4-D and 1-naphthalene acetic acid (NAA) improves the efficiency of CIM because these compounds cannot be exported by PIN-FORMED (PIN) proteins and are poorly metabolized. Auxin-induced degradation of IAA28 then promotes the expression of GATA23 to confer founder cell identity. Mitotic competence of pericycle cells also relies on ABERRANT LATERAL ROOT FORMATION 4 (ALF4), the knockout of which impairs both lateral root formation and shoot regeneration [37]. Intriguingly, repression of $A L F 4$ by very-long-chain fatty acids confines the capacity of pericycle cells to form callus [38].

\subsection{Callus Formation}

In-vitro-induced callus resembles root primordia on a morphological and transcriptional level, even when derived from aerial organs $[36,39,40]$. Indeed, transcriptome comparison revealed similar expression profiles in lateral root tips and organogenic calli, which show organized expression of root meristem markers such as WOX5, SHORT ROOT (SHR), SCARECROW (SCR), PLT1E2, PIN1, QUIESCENT CENTER 25 (QC25), ROOT CLAVATA HOMOLOG 1 (RCH1), and GLABRA2 (GL2). Accordingly, callus formation on CIM proceeds through a similar developmental program as lateral root initiation $[7,20,34]$. Auxin accumulation in the founder cells mediates degradation of IAA14/SLR, which releases ARF7 and ARF19 that upregulate LBD16-18 and LBD29, involving ATXR2-mediated H3K36me3 deposition [4,41,42]. JUMONJI C DOMAIN-CONTAINING PROTEIN 30 (JMJ30) also associates with the ARF-ATXR2 complex to promote $L B D$ expression by removing repressive $\mathrm{H} 3 \mathrm{~K} 9 \mathrm{me} 3$ marks [43], while the BRASSINOSTEROID INSENSITIVE 2 (BIN2) kinase integrates temperature sensitivity into this cascade by enhancing the transcriptional activity of ARF7E19 and LBD genes [44]. In turn, LBD18 reinforces the auxin signal by promoting ARF7\&19, and, together with LBD33, it triggers cell proliferation via transcriptional activation of E2 PROMOTER BINDING FACTOR $a(E 2 F a)$, which associates with DIMERIZATION PARTNERs (DPs) to stimulate DNA replication genes [7,11]. Auxin also downregulates KIP-RELATED PROTEIN (KRP) 2, -3, and -7, which are cyclin-dependent kinase (CDK) inhibitors, through a reduction in PROPORZ1 (PRZ1)-deposited H3K9ac and H3K14ac [34]. KRPs are further silenced via H4R3 dimethylation and alternative splicing of RELATED TO KPC1 (RKP) by PROTEIN ARGININE METHYLTRANSFERASE 5 (PRMT5) [45]. A series of anticlinal and periclinal divisions then lead to the formation of a dome-shaped protuberance $[4,35]$, which is further assisted by LBD-mediated cell wall modifications. For instance, LBD18 directly induces EXPANSIN 4 (EXP4), LBD29 targets PECTIN METHYLESTERASE 2 (PME2), and association of LBD16 with bZIP59 activates a FAD-binding Berberine enzyme to oxidize monolignols in the cell wall $[7,46,47]$. Upon proliferation of the callus, expression of the pericycle marker J0121 diffuses, concomitant with the acquisition of root identity [20]. Cytokinin interferes in callus formation via ARR7\&15 and ARR1\&21, which are, respectively, A-type and B-type response regulators with a negative and positive effect on the outcome, and it has been proposed that CK-control of the cell cycle is moderated by ESR1\&2 [34,48]. These AP2/ERF TFs can directly induce CYCD1;1 and OBF BINDING PROTEIN 1 (OBP1), in turn activating CYCD3;3 and shortening the G1 phase to enable cell cycle reentry. The interplay between auxin and cytokinin during callus initiation is at least partly directed by microRNAs, as miR160 can repress the process by targeting ARF10 to relieve the direct suppression of ARR15 [49].

\subsection{Pluripotency Acquisition}

On CIM, calli also acquire competence to respond to shoot inductive cues as activation of key shoot meristem regulators like WUSCHEL (WUS) on SIM requires several days of CIM preincubation [35]. Recently, it was found that transient expression of root stem cell maintenance genes, including WOX5, PLT1E2, SCR, and SHR, in a subset of callus cells confers pluripotency, but how these are activated is not completely understood $[11,19,50]$. One pathway involves the induction of PLT3, PLT5, and PLT7 by 
auxin, followed by direct upregulation of PLT1 and PLT2, as well as the shoot determinants CUC1 and CUC2 [51]. The latter have been put forward as markers of pluripotency acquisition, along with AHK4, IAA20, and ARABIDOPSIS CRINKLY 4 (ACR4) [4]. Notably, the WOX11-LBD16 pathway involved in de novo root regeneration from leaf explants also contributes to the lateral root primordium (LRP) character of callus on CIM [52]. Furthermore, the acquisition of shoot competence depends on cell cycle reentry and progressive epigenetic changes [21,35]. For instance, HAG1 catalyzes the acetylation of histone $\mathrm{H} 3$ at WOX5E14, PLT1E2, and SCR loci to potentiate their transcription on CIM [50]. During callus formation from leaf blades, histone deacetylation by HDA3\&9, as well as genome-wide changes in H3K27me3 levels installed by the PRC2 components CURLY LEAF (CLF), SWINGER (SWN), and EMBRYONIC FLOWER 2 (EMF2), are required to silence leaf-specific gene expression, while removal of $\mathrm{H} 3 \mathrm{~K} 27 \mathrm{me} 3$ at loci involved in auxin signaling and root development enables leaf-to-callus transition [53,54]. Many other regeneration determinants, such as WOX5E11, WUS, and SHOOT MERISTEMLESS (STM), undergo dynamic changes in PRC2-mediated H3K27me3 during organogenesis, but the machinery underlying histone demethylation is still poorly characterized [10,55]. However, LYSINE-SPECIFIC DEMETHYLASE 1-LIKE 3 (LDL3) was found to remove H3K4me2 during callus formation to prime the activation of SAM-patterning genes (e.g., ARR12, WUS, and CLAVATA3 (CLV3)) on SIM [56]. Besides histone modification, DNA methylation provides another mechanism of epigenetic reprogramming, and it was proposed that reactivation of the cell cycle by auxin, followed by continued cell division in the presence of high cytokinin levels on SIM, causes a dilution in the methylation status of key regeneration genes [57]. Accordingly, mutation of CMT3 and DOMAINS REARRANGED METHYLTRANSFERASE (DMR) 1 and 2 allows to bypass CIM preincubation for WUS expression and shoot regeneration.

\subsection{Transdifferentiation}

It has been proposed that de novo establishment of the shoot apical meristem on SIM reflects transdifferentiation from root to shoot identity instead of a true de- and redifferentiation process [36,39,58]. After all, dedifferentiation has often been vaguely inferred from renewed cell division and morphological changes, which do not necessarily reflect reversal to an embryonic state. Its role in animal regeneration systems is currently under reconsideration as well because blastema formed during limb regeneration in salamanders were found to comprise a heterogenous pool of progenitors that regenerate tissues within their original lineage [11,58]. Adult mammalian cells also appear to retain the potential for transdifferentiation, as ectopic expression of a few TFs can induce lineage reprogramming without reversal to a stem cell identity. Similarly, LRP in plants can be directly converted into shoot primordia during a narrow developmental window that supports repetitive reversal of the organogenetic program by wavered application of 2-isopentenyladenine (2-iP) and NAA [59]. Intriguingly, the switch is paralleled by reduced root marker expression and upregulation of shoot regulators or vice versa, resulting in altered cell division patterns after a mitotic pause. Transcriptome comparison revealed that LRPs undergoing direct conversion resemble regenerating calli and both processes depend on the rapid rearrangement of complementary auxin and cytokinin domains, as well as WOX5-expressing stem cells, for transition [59].

\subsection{Shoot Promeristem Formation}

Upon transfer to SIM, overlapping signaling domains of auxin and cytokinin diverge into mutually exclusive regions, thereby partitioning cellular identity through complementary expression of CUC2 and WUS [7,22,25,60]. These developmental regulators initially show broad activity throughout the callus, after which CUC2 is restricted to areas with high auxin levels and rapidly dividing cells, whereas WUS is confined to cells marked by AHK4 and strong cytokinin responses [4,11]. As discussed before, CUC1E2 are upregulated by PLT3, PLT5, and PLT7 during CIM preincubation, but also by ESR1\&2 in response to cytokinin and wound-induced WIND1 [31,51,61]. Their combined expression activates STM in a surrounding ring of cells and modulates polar localization of PIN1 to direct the auxin flow towards 
the apical tip $[4,11,19]$. Subsequently, STM is expressed throughout the shoot promeristem and restricts CUC genes to the peripheral zone, where they induce LIGHT SENSISTIVE HYPOCOTYLS (LSH) 3 and 4 , which suppress differentiation in the organ boundary $[60,62]$. On the other hand, WUS has emerged as a master regulator of stem cell maintenance in the SAM as overexpression causes ectopic shoot formation, while wus mutants fail to regenerate $[19,21,26]$. This homeobox TF is directly activated by cytokinin via the B-type response regulators ARR1, ARR2, ARR10, and ARR12, that physically interact with HD-ZIP III TFs PHABULOSA (PHB), PHAVOLUTA (PHV), and REVOLUTA (REV), to spatially confine WUS expression to shoot progenitor cells [26,63-65]. Oddly, mutation of ARGONAUTE 10 (AGO10) was found to enhance pro-SAM formation by releasing miR165E166 to degrade HD-ZIP III mRNAs [66], while this would be expected to hamper ARR-mediated WUS transcription, in agreement with other reports showing that phb phv rev and inducible miR165/166 lines fail to regenerate [26]. Moreover, HD-ZIP III TFs stimulate other shoot determinants such as STM and RAP2.6L [7,67,68], and B-type ARRs also promote WUS indirectly by repressing YUC1\&4-modulated auxin biosynthesis [64]. In turn, WUS reinforces cytokinin responses by suppressing A-type ARRs, while further downregulating auxin-induced root markers by rheostatic gating of the entire auxin pathway through direct transcriptional repression and TPL-assisted association with histone deacetylases [69-71]. Conversely, direct suppression of IPT5 by ARF3 and inhibition of STM-mediated IPT7 activation maintains auxin signaling at the peripheral and apical zone of the primordium [4,25]. WUS is only induced after 2-3 days on SIM because it harbors the repressive H3K27me3 mark maintained by PRC2 components CLF and SWN, removal of which depends on cytokinin-controlled cell cycle progression and possibly involves active demethylation by EARLY FLOWERING 6 (ELF6) and RELATIVE OF EARLY FLOWERING 6 (REF6) [26,53]. The WUS locus also undergoes dynamic changes in the levels of other repressive histone modifications (e.g., H3K9me3) and activating marks (e.g., H3K9ac and H3K4me3), which is modulated by LDL3 and JMJ14 (H3K4 demethylases), KRYPTONITE (KYP; an H3K9 methyltransferase) and HAG1 [56,72]. Moreover, DRM1\&2, CMT3, and MET1 normally silence WUS via DNA methylation, which is gradually lost on SIM [57]. It was shown that cytokinin first upregulates MET1 through CYCD3-mediated activation of E2Fa to prevent early WUS transcription, after which MET1 expression migrates to the outer layers of the callus and the resulting dilution of DNA methylation enables WUS activation by ARRs [73]. WUS is additionally regulated by intrinsic factors such as miR156, transcript levels of which decrease in aging plants, leading to the accumulation of SPL9-group proteins that bind B-type ARRs to attenuate cytokinin signals $[19,74]$. Ultimately, WUS is confined to the center of the dome-shaped promeristem when CUC1E2 activity shifts to the peripheral zone and STM is expressed throughout the primordium $[11,60]$.

\subsection{SAM Patterning and Shoot Outgrowth}

A functional SAM consists of an organizing center (OC) between a lower rib meristem and a central zone with slowly dividing stem cells at the apex, surrounded by a peripheral zone undergoing rapid proliferation [75,76]. While the OC maintains the stem cell niche, daughter cells of the central zone are displaced sideways into the peripheral zone or downwards into the rib meristem, where they respectively differentiate into lateral organs (i.e., leaves or flowers) or contribute to stem formation [4]. The balance between the meristematic regions is governed by WUS, which is produced in the OC and migrates to the surrounding layers to induce CLV3, in turn blocking WUS expression in the central zone and the rib meristem through CLV1\&2 and CORYNE (CRN) [4,75]. This feedback loop is reinstated during shoot regeneration as CLV3 is upregulated after WUS expression is established in the center of the shoot promeristem [60]. In this last stage, PIN1 orientation is shifted to the incipient leaf primordia by PINOID (PID) to redistribute auxin maxima and enable phyllotactic patterning of the meristem [4]. PIN1 and PID are further regulated by interaction with ESR1\&2, and the influx carriers AUX1 and LAX1-3 were proposed to contain auxin in the epidermal cell layer, which is marked by ARABIDOPSIS THALIANA MERISTEM LAYER 1 (ATML1) [60,77,78]. REVOLUTA (REV) and FILAMENTOUS FLOWER (FIL) determine adaxial/abaxial polarity in the newly formed organ 
primordia. Notably, the chromatin modifier ARABIDOPSIS TRITHORAX 4 (ATX4) is essential for shoot identity determination as it promotes the expression of ARABIDOPSIS THALIANA HOMEOBOX GENE 1 (ATH1), KNOTTED1-LIKE HOMEOBOX GENE 4 (KNAT4), SAWTOOTH (SAW) 1 and 2, TCP10, and YABBY5 (YAB5) by H3K4me3 deposition $[19,79]$.

\section{Mapping Natural Variation in the Organogenic Potential at the Genetic Level}

\subsection{Variation in Arabidopsis thaliana}

Several studies have reported substantial variation in the regenerative potential of natural Arabidopsis thaliana accessions, and various strategies have been applied to map such differences at the genetic level (Table 1; [80]) [81,82]. However, early attempts suffered from limited mapping resolution and often failed to identify causative genes because of poor annotations. For instance, variation among recombinant inbred lines (RILs) between Col and Ler was linked to one common region (85-89 cM) on chromosome 1 underlying callus formation and shoot regeneration from leaf explants, whereas several areas on chromosomes 4 (e.g., 24-32 cM) and 5 (e.g., 36-40 cM) specifically contributed to shoot regeneration from roots or leaves [83]. Combined with transgressive segregation (i.e., the observation that some descendant RILs showed more extreme phenotypes than the parental lines), the authors concluded that regeneration is determined by multiple loci acting at various stages and that genetic requirements also depend on the explant type. While no specific genes were pinpointed, the marker on chromosome 1 was found to be near SHOOT REDIFFERENTIATION DEFECTIVE 1 (SRD1; a gene underlying temperature-sensitive redifferentiation from roots to shoots), although it also overlaps with RECEPTOR-LIKE PROTEIN KINASE 1 (RPK1; $91 \mathrm{cM}$ on chromosome 1), which was later discovered by Motte et al. $[81,83,84]$. Curiously, composite interval mapping with the Col x Ler RILs also revealed quantitative trait loci (QTLs) on chromosomes 1, 4, and 5, but at different positions (respectively around 12.5, 60.9, and $106.7 \mathrm{cM}$ ) [85]. Binning lines that carried the superior Col allele or the Ler variant of the major QTL on chromosome 5, while fixing the beneficial Ler alleles at the minor loci and contrasting gene expression patterns in both genotype pools uncovered 845 differentially expressed genes, including ARR18, AGL6, and AT4G36590 (2 MADS-box TFs), AT5G50820 (a NO APICAL MERISTEM family member related to CUC1E2), HOMEOBOX-LEUCINE ZIPPER PROTEIN 17 (HB17), and 3 subtilases (AT1G01900, AT5G59120, and AT4G26330). On the other hand, analysis of Ler x Cvi RILs respectively identified 8,5 , and 4 loci for shoot, root, and callus formation from leaf or root explants [82]. Only a minority of QTLs were shared between different explant types and regeneration protocols (e.g., 115-130 cM on chromosome 1, 40-60 cM on chromosome 2, and 10-30 cM and 70-95 cM on chromosome 5), again indicating the occurrence of common determinants acting besides a multitude of context-dependent factors. One shoot-specific QTL (0-20 cM on chromosome 1$)$ was proposed to represent allelic variants of SRD3, ROOT REDIFFERENTIATION DEFECTIVE 4 (RRD4), CYTOKININ HYPERSENSITIVE 1 (CKH1), INCREASED ORGAN REGENERATION 1 (IRE1), or AUXIN RESISTANT 1 (AXR1) [82].

More recently, linkage mapping with RILs between Nok-3 and Ga-0 revealed five major QTLs responsible for the difference in de novo shoot organogenesis between these lines [81]. One of these QTLs was refined by local association analyses based on 88 accessions, which pinpointed a single nucleotide polymorphism (SNP) in the gene encoding RPK1, altering the conformation of its putative ligand-binding domain. RPK1 was found to be expressed in dividing pericycle cells during CIM preincubation and loss-of-function impaired de novo shoot formation [81]. This leucin-rich repeat (LRR) receptor-like kinase is involved in ABA signaling and is accordingly required for abiotic stress tolerance, but it also interferes in embryonic patterning and formation of cotyledon primordia, supported by its importance for PIN1 localization and WOX5 expression [86-88]. Notably, the RPK1 homolog RPK2 regulates WUS expression to control SAM maintenance, and, although this function is not conserved in RPK1 [89], the two proteins show redundancy during embryogenesis and their sequences mainly differ in the kinase domain $[81,86]$, indicating that they might simply respond to different external 
cues. Nonetheless, SAM-less monocotyledonous rpk1 mutants are capable of expressing shoot markers and occasionally regenerate ectopic shoot meristems [90]. Motte et al. further showed that early and late regeneration characteristics are poorly correlated, indicating that the shoot organogenetic process can be inhibited at several intermediate stages and chlorophyll maturation does not ensure successful shoot determination [11,81]. Another recent study describing the effects of thioredoxin-mediated ROS homeostasis on shoot regeneration from root explants reported that 6 SNPs in DCC1 (encoding a thiol-disulfide oxidoreductase family protein with a conserved DxxCxxC motif) were strongly linked to regenerative variation among 48 ecotypes [91]. DCC1 localizes to the mitochondria of the inner callus cells, where it reduces CARBONIC ANHYDRASE 2 (CA2; a subunit of the respiratory chain NADH dehydrogenase complex I) by direct interaction. Mutation of either DCC1 or CA2 caused increased ROS levels by reducing the activity of complex I, in turn hampering shoot regeneration by downregulating essential genes for callus and shoot promeristem formation (e.g., WOX5E11, KNAT1-2E4, WUS, CLV3, STM, and CUCS) and lowering the expression of auxin biosynthesis and signaling genes (e.g., TAA1, YUC2, YUC4, YUC5, YUC9, GRETCHEN HAGEN 3.6 (GH3.6), and SMALL AUXIN UPREGULATED 51 (SAUR51)), potentially via redox modification of PHV and TCP15 [91]. Moreover, mutation of the two missense SNPs in DCC1 abolished the interaction with CA2 and, accordingly, the superior haplotype was associated with lower ROS levels. It is important to note, however, that while DCC1 may be correlated with variation in shoot regeneration, it might not reflect a rate-limiting factor in natural populations as it was not discovered by mapping (i.e., no other loci were considered in this analysis).

Notably, a poor overlap is observed between QTLs obtained by linkage mapping using Nok-3 x Ga-0, Ler x Col, or Ler x Cvi RILs, highlighting the complex polygenic nature of regeneration (Table 1) [81-83,85]. Moreover, it is likely that variation within individual RIL sets partially depends on specific factors, and the use of different explants, protocols, and environmental conditions for regeneration can alter the phenotypic distribution and thus affect the underlying QTLs. Just recently, we performed a full-scale genome-wide association study (GWAS) to dissect variation in shoot regeneration from roots and several related in vitro traits among 190 natural Arabidopsis accessions under different conditions [80]. In agreement with the genetic complexity reported before, this analysis uncovered a myriad of quantitative trait genes (QTGs), including ARFs and ARRs, MYB and AP2/ERF2 family TFs, miRNAs, receptor-like kinases, F-box proteins, chromatin remodelers, and various biosynthetic and cell wall modifying enzymes, the majority of which were protocol and trait-specific $(\sim 95 \%)$, leading us to hypothesize that shoot regeneration is governed by a multitude of conditional fine-tuning factors and a few universal master regulators. A shift in rate-limiting QTGs under different settings could also explain the heterogeneous results obtained in other surveys. Plotting the number of associated phenotypes against a score for prior links with organogenesis based on literature allowed us to distinguish four categories of candidate genes, showcasing WUS as a major determinant of regeneration. We showed that its expression correlates with the regeneration potential and found numerous other a priori candidates with more specific functions (e.g., IAA9, ARF4, ARR2, LSH4, CLE2, MYB118, FUS3, miR393A, and miR394A). Moreover, our GWAS also exposed several novel QTGs that might act as master regulators, including AT3G09925 (a pollen Ole e1 allergen and extensin family gene), SUPERMAN (SUP), EMBRYO SAC DEVELOPMENT ARREST (EDA40), and DNA-BINDING WITH ONE FINGER 4.4 (DOF4.4). Finally, the genetic architecture of in planta shoot growth was shown to be complex as well, comprising around 112 QTLs grouped in hotspots on chromosomes 1, 2 and 5, of which $\sim 10 \%$ were considered major QTLs (e.g., CRYPTOCHROME 2 (CRY2)), and the rest were loci with intermediate or minor effects that occasionally interacted with drought stress [92]. Many of the linked regions differed across RIL sets, showed epistatic effects, and contained multiple subpeaks. 
Table 1. Overview of QTL mapping studies on regeneration in Arabidopsis thaliana. The QTL and QTG columns respectively specify the number (and chromosomal position) of quantitative trait loci and highlight quantitative trait genes (plausible candidates are bracketed).

\begin{tabular}{|c|c|c|c|c|c|c|}
\hline Species & Population & Method & Phenotype(s) & $Q T L(s)$ & $Q T G(s)$ & Reference \\
\hline \multirow{6}{*}{ Arabidopsis thaliana } & Col x Ler RILs & $\begin{array}{l}\text { MAPMAKER QTL } \\
\text { analysis }\end{array}$ & $\begin{array}{l}\text { Callus and shoot } \\
\text { formation from } \\
\text { root or leaf } \\
\text { explants }\end{array}$ & $9(\operatorname{chr} 1,4$, and 5$)$ & (SRD1) & Schiantarelli et al. 2001 [83] \\
\hline & Col x Ler RILs & $\begin{array}{c}\text { Composite } \\
\text { interval mapping }\end{array}$ & $\begin{array}{c}\text { Shoot } \\
\text { regeneration from } \\
\text { root explants }\end{array}$ & $3(\operatorname{chr} 1,4$, and 5$)$ & $\begin{array}{c}\text { ARR18, } \\
\text { AGL6, HB17, } \\
\text { AT4G36590, } \\
\text { AT5G50820, } \\
\text { AT1G01900, } \\
\text { AT5G59120, } \\
\text { AT4G26330 }\end{array}$ & Lall et al. 2004 [85] \\
\hline & Ler x Cvi RILs & $\begin{array}{l}\text { QTL interval } \\
\text { mapping }\end{array}$ & $\begin{array}{l}\text { Shoot or root } \\
\text { regeneration from } \\
\text { root or leaf } \\
\text { explants }\end{array}$ & 17 (chr 1, 2, and 5) & $\begin{array}{c}(S R D 3, \\
\text { RRD4, IRE1, } \\
\text { CKH1, } \\
\text { AXR1) }\end{array}$ & Velázquez et al. 2004 [82] \\
\hline & Nok-3 x Ga-0 RILs & $\begin{array}{l}\text { Linkage and } \\
\text { association } \\
\text { mapping }\end{array}$ & $\begin{array}{c}\text { Shoot } \\
\text { regeneration from } \\
\text { root explants }\end{array}$ & 5 (chr 1-3) & RPK1 & Motte et al. 2014 [81] \\
\hline & 48 ecotypes & $\begin{array}{c}\text { Linkage } \\
\text { disequilibrium } \\
\text { analysis }\end{array}$ & $\begin{array}{c}\text { Shoot } \\
\text { regeneration from } \\
\text { root explants }\end{array}$ & 1 (chr 5) & DCC1 & Zhang et al. 2018 [91] \\
\hline & $\begin{array}{l}170 \text { natural } \\
\text { SALK strains }\end{array}$ & GWAS & $\begin{array}{l}\text { Shoot } \\
\text { regeneration from } \\
\text { root explants }\end{array}$ & $86(\operatorname{chr} 1-5)$ & $\begin{array}{c}\text { WUS, SUP, } \\
\text { AT3G09925, } \\
\text { DOF4.4, } \\
\text { EDA40, } \\
\text { QUL2, } \\
\text { URH1, RLP9, } \\
\text { QKY, ARF20, } \\
\text { MSL3, } \\
\text { DREB1A, } \\
\text { WAVH2, } \\
\text { MIR393A, }\end{array}$ & Lardon et al. 2020 [80] \\
\hline
\end{tabular}

\subsection{Variation in Other Species}

\subsubsection{Monocot Crops}

The creation of transgenic rice plants for breeding and functional genome research relies on Agrobacterium-mediated transformation of in vitro cultures, and, although efficient protocols have been established for callus induction and regeneration from mature seeds, many commercial cultivars (e.g., Koshihikari) are recalcitrant to this system $[93,94]$. Like in Arabidopsis, early endeavors to map variation in several callus induction traits by following the segregation of amplified/restriction fragment length polymorphism (AFLP/RFLP) markers after crossing strongly and poorly regenerating (typically japonica and indica) varieties uncovered a myriad of QTLs across the 12 chromosomes, some of which could be used for marker-assisted selection, but failed to identify specific genes (Table 2) [93,95-97]. However, Nishimura et al. applied map-based cloning to refine one of four QTLs underlying the differential regeneration abilities of Koshihikari and Kasalath strains, pinpointing a locus on the short arm of chromosome $1(45.4 \mathrm{cM})$, designated PROMOTER OF SHOOT REGENERATION 1 (PSR1) [98]. Cloning of all four genes in the region suggested that PSR1 is a putative ferredoxin-nitrite reductase with lower expression and activity in poorly regenerating Koshihikari plants. Another study monitored simple sequence repeat (SSR) markers in chromosome segment substitution lines (CSSLs) between Nipponbare and Zhenshan 97B to identify 29 QTLs for 4 callus traits under 2 protocols, which were grouped in hotspots on chromosomes 1, 3, and 10 [99]. More recently, high-quality genetic maps, including SNPs among two different RIL sets, uncovered largely non-overlapping batches of 8 and 25 QTLs (highlighting two major loci on chromosomes 3 and 7), most of which had not been discovered before $[94,100]$. The dissimilarity in QTLs was attributed to variable culture conditions, parental lines, and mapping approaches. Moreover, phenotypic contributions usually range between $6 \%$ and $26 \%$ (while older QTLs likely explain more variation because they contain multiple subassociations), implying comparable genetic complexity as in Arabidopsis [101]. Accordingly, a GWAS 
on 510 sequenced rice accessions revealed 88 loci correlated to the rate, speed, and time of callus induction, 21 of which were located in previously reported QTLs [102]. Among the candidate genes, three were orthologs of callus formation genes in Arabidopsis: CROWN ROOTLESS 1 (CRL1; orthologous to LBD17/29), OsBBM1 (an ortholog of BBM), and OsSET1 (a SET-domain-containing gene, orthologous to $S W N$ ). While the latter was downregulated during in vitro culture, expression levels of the former two increased, consistent with the repressive and promotive roles of their respective counterparts in Arabidopsis. Fourteen additional candidates were put forward based on $p$-values, annotations, and expression patterns, including a putative thioredoxin, two AP2-domain-containing proteins, and OsIAA10, RNAi knockdown of which impeded callus induction and auxin responsivity [102]. Lastly, an allele of BROWNING OF CALLUS 1 (BOC1) from wild rice was found to reduce callus browning in indica cultivars by decreasing cell death and senescence in response to oxidative stress [103].

QTL mapping of regeneration traits has been attempted in several other cereal crops such as maize [104-106], wheat [107-109], and barley [110-112] (Table 2). Early studies in maize using the highly and lowly regenerable A188 and B73 inbred lines identified a major QTL on chromosome 3 [104] that was recently exploited to create a germplasm with enhanced tissue culture responses, nearly isogenic to the elite B73 [106]. Fine mapping of this locus revealed a 3053-kb region containing multiple candidate genes such as ALDOLASE 1 (ALD1), ZmWOX2A, and ZmWOX5B. Furthermore, a multilocus GWAS for five embryonic callus traits using 43427 SNPs in 144 inbred maize lines identified 63 common quantitative trait nucleotides (QTNs), 15 of which were retained in multiple environments [105]. A total of 40 candidate genes were found, including TFs and kinases involved in auxin transport, cell fate specification, seed germination, embryo development, and transgenic callus regeneration. Particular attention was given to WOX2, showing elevated expression in a strong regenerator, which is consistent with the role of WUS in Arabidopsis organogenic variation [80] and the observation that immature maize embryos transformed with WUS2- or BBM-expressing constructs regenerate more seedlings [113]. In wheat, DArT (diversity arrays technology)-assisted linkage mapping of callus induction and regeneration from mature embryos in RILs between a synthetic hexaploid (SHW-L1) and a commercial cultivar (Chuanmai 32) uncovered 6 QTLs on chromosomes 1A\&D, 3B, 4\&5A, and 6D, explaining up to $12 \%$ of phenotypic variation each and confirming the importance of group 1, 3, and 5 chromosomes established by previous QTL analyses on immature embryos and microspore cultures $[108,109,114]$. Notably, many loci were novel and only detected in one growing season, again highlighting the effect of the environment on rate-limiting regeneration determinants. Three major loci for transformation amenability were discovered in barley, and it was later shown that introgression of the corresponding alleles from Golden Promise plants into recalcitrant cultivars improves transformation efficiency [115]. Higher density mapping of these QTLs with SNP markers suggested that they might be linked to the barley homologs of WUS2 and BBM [116]. Finally, a barley map based on expressed sequence tags enabled the detection of 8 regions associated with green or albino plant regeneration [112]. Four of these overlap with previously identified QTLs (on chromosomes $2 \mathrm{H}, 3 \mathrm{H}, 6 \mathrm{H}$ and $7 \mathrm{H}$ ), and underlying genes were linked to hormone biosynthesis and signaling, cell cycle regulation, chloroplast maturation, and shoot meristem development. Specific examples include a ferredoxin-nitrite reductase, cyclins and CDKs, ET biosynthetic enzymes, AP2 TFs, and orthologs of STM, PICKLE (PKL), LEC, AGL24, and CUCs. 
Table 2. Nonexhaustive overview of QTL mapping studies on regeneration in monocot crops since 2000. The QTL and QTG columns respectively specify the number (and chromosomal position) of quantitative trait loci and highlight quantitative trait genes (plausible candidates are bracketed).

\begin{tabular}{|c|c|c|c|c|c|c|}
\hline Species & Population & Method & Phenotype(s) & $Q T L(s)$ & QTG(s) & Reference \\
\hline \multirow{9}{*}{ Oryza sativa } & $\begin{array}{c}\text { Norin } 1 \times \text { Tadukan } \\
\mathrm{F}_{2}\end{array}$ & $\begin{array}{l}\text { QTL interval } \\
\text { mapping }\end{array}$ & $\begin{array}{c}\text { Shoot } \\
\text { regeneration from } \\
\text { mature } \\
\text { seed-derived } \\
\text { callus }\end{array}$ & $2(\operatorname{chr} 2$ and 4$)$ & - & Takeuchi et al. 2000 [96] \\
\hline & $\begin{array}{l}\text { Milyang } 23 x \\
\text { Gihobyeo RILs }\end{array}$ & RFLP analysis & $\begin{array}{c}\text { Shoot } \\
\text { regeneration from } \\
\text { mature } \\
\text { seed-derived } \\
\text { callus }\end{array}$ & $6(\mathrm{chr} 1-3$ and 11$)$ & - & Kwon et al. 2001 [97] \\
\hline & $\begin{array}{c}\text { Koshihikari x } \\
\text { Kasalath } \mathrm{BC}_{1-3} \mathrm{~F}_{2}\end{array}$ & $\begin{array}{l}\text { Map-based } \\
\text { cloning }\end{array}$ & $\begin{array}{c}\text { Shoot } \\
\text { regeneration from } \\
\text { mature } \\
\text { seed-derived } \\
\text { callus } \\
\end{array}$ & 4 (chr 1-3 and 6) & PSR1/NIR & Nishimura et al. 2005 [98] \\
\hline & $\begin{array}{l}\text { Koshihikari x } \\
\text { Kasalath } \mathrm{BC}_{1} \mathrm{~F}_{3} \\
\text { and NILs }\end{array}$ & $\begin{array}{l}\text { MAPMAKER QTL } \\
\text { analysis }\end{array}$ & $\begin{array}{l}\text { Callus induction } \\
\text { and regeneration } \\
\text { from mature seeds }\end{array}$ & $8(\operatorname{chr} 1,4$, and 9$)$ & - & $\begin{array}{l}\text { Taguchi-Shiobara et al. } \\
2006 \text { [93] }\end{array}$ \\
\hline & $\begin{array}{l}\text { Nipponbare } \mathrm{x} \\
\text { Zhenshan 97B } \\
\text { CSSLs }\end{array}$ & $\begin{array}{l}\text { Stepwise } \\
\text { regression of } \\
\text { CSSLs }\end{array}$ & $\begin{array}{l}\text { Callus induction } \\
\text { and regeneration } \\
\text { from mature seeds }\end{array}$ & $\begin{array}{l}29(\mathrm{chr} 1,3, \\
\text { and 10) }\end{array}$ & - & Zhao et al. 2009 [99] \\
\hline & $\begin{array}{l}\text { Nipponbare } x \\
\text { 93-11 RILs }\end{array}$ & $\begin{array}{c}\text { Composite } \\
\text { interval mapping }\end{array}$ & $\begin{array}{l}\text { Callus induction } \\
\text { and regeneration } \\
\text { from mature seeds }\end{array}$ & 25 (chr 3 and 7$)$ & - & Li et al. 2013 [94] \\
\hline & $\begin{array}{c}\text { Pei'ai 64s x } \\
\text { Yangdao } 6 \text { RILs }\end{array}$ & QTL mapping & $\begin{array}{l}\text { Callus induction } \\
\text { from mature seeds }\end{array}$ & $\begin{array}{l}8(\operatorname{chr} 5-7,9 \\
\text { and 10) }\end{array}$ & - & Tian et al., 2013 [100] \\
\hline & $\begin{array}{l}510 \text { natural } \\
\text { accessions }\end{array}$ & GWAS & $\begin{array}{l}\text { Callus induction } \\
\text { from mature seeds }\end{array}$ & 88 (chr 1-12) & $\begin{array}{l}\text { OsBBM1, } \\
\text { OsSET1, } \\
\text { OsIAA10, } \\
\text { CRL1, .. }\end{array}$ & Zhang et al. 2019 [102] \\
\hline & Teqing x YIL25 $\mathrm{F}_{2}$ & $\begin{array}{l}\text { Map-based } \\
\text { cloning }\end{array}$ & Callus browning & $1(\operatorname{chr} 3)$ & $B O C 1$ & Zhang et al. 2020 [103] \\
\hline \multirow[b]{2}{*}{ Zea Mays } & A188 x B73 NILs & $\begin{array}{c}\text { Segregation } \\
\text { distortion analysis }\end{array}$ & $\begin{array}{l}\text { Callus induction } \\
\text { and regeneration } \\
\text { from mature } \\
\text { embryos }\end{array}$ & 1 (chr 3) & $\begin{array}{c}\text { ALD1, } \\
\text { ZmWOX2A, } \\
\text { ZmWOX5B }\end{array}$ & Salvo et al. 2018 [106] \\
\hline & 144 inbred lines & GWAS & $\begin{array}{l}\text { Callus induction } \\
\text { and regeneration } \\
\text { from immature } \\
\text { embryos }\end{array}$ & $63($ chr 1-10) & 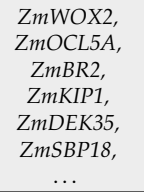 & Ma et al. 2018 [105] \\
\hline \multirow{3}{*}{ Triticum aestivum } & $\begin{array}{l}\text { Wangshuibai x } \\
\text { Nanda } 2419 \text { RILs }\end{array}$ & $\begin{array}{l}\text { Simple and } \\
\text { composite interval } \\
\text { mapping }\end{array}$ & $\begin{array}{l}\text { Callus induction } \\
\text { and regeneration } \\
\text { from mature } \\
\text { embryos }\end{array}$ & $\begin{array}{c}13(\operatorname{chr} 2 \mathrm{~A}, 2 \mathrm{D}, 5 \mathrm{~A}, \\
5 \mathrm{~B}, \text { and } 5 \mathrm{D})\end{array}$ & - & Jia et al. 2007 [108] \\
\hline & $\begin{array}{l}\text { Svilena } x \\
\text { Jensen } \mathrm{F}_{3}\end{array}$ & $\begin{array}{l}\text { DArT-based QTL } \\
\text { mapping }\end{array}$ & $\begin{array}{l}\text { Green plantlet } \\
\text { regeneration from } \\
\text { microspore } \\
\text { cultures }\end{array}$ & $2(\mathrm{chr} 1 \mathrm{~B}$ and 7B) & - & Nielsen et al. 2015 [114] \\
\hline & $\begin{array}{l}\text { Chuanmai } 32 x \\
\text { SHW-L1 RILs }\end{array}$ & $\begin{array}{l}\text { DArT-based QTL } \\
\text { mapping }\end{array}$ & $\begin{array}{l}\text { Callus induction } \\
\text { and regeneration } \\
\text { from mature } \\
\text { embryos }\end{array}$ & $\begin{array}{c}6(\operatorname{chr} 1 \mathrm{~A}, 1 \mathrm{D}, 3 \mathrm{~B} \\
4 \mathrm{~A}, 5 \mathrm{~A}, 6 \mathrm{D})\end{array}$ & - & Ma et al. 2016 [109] \\
\hline \multirow{4}{*}{ Hordeum Vulgare } & $\begin{array}{l}\text { Azumamugi x } \\
\text { Kanto Nakate } \\
\text { Gold RILs }\end{array}$ & $\begin{array}{c}\text { Composite } \\
\text { interval mapping }\end{array}$ & $\begin{array}{l}\text { Callus induction } \\
\text { and shoot } \\
\text { regeneration from } \\
\text { immature embryo } \\
\text { cultures }\end{array}$ & $\begin{array}{l}8(\mathrm{chr} 1-3 \mathrm{H}, 5 \mathrm{H}, \\
\text { and } 7 \mathrm{H})\end{array}$ & $\begin{array}{l}\text { UZU, SHD1, } \\
\text { VRS1 }\end{array}$ & Mano et al. 2002 [111] \\
\hline & $\begin{array}{l}\text { Steptoe } x \\
\text { Morex DHs }\end{array}$ & $\begin{array}{l}\text { EST-based linkage } \\
\text { mapping }\end{array}$ & $\begin{array}{l}\text { Green and albino } \\
\text { plant regeneration }\end{array}$ & 8 (chr 1-7H) & $\begin{array}{c}\text { HvSTM, } \\
\text { HvPKL, } \\
\text { HvLEC, } \\
\text { HvBBM, } \\
\text { HvESR1, } \\
\text { HvCUC, } \\
\text { HvAGL24, } \\
\ldots\end{array}$ & Tyagi et al. 2010 [112] \\
\hline & $\begin{array}{l}\text { Haruna Nijo } x \\
\text { Golden } \\
\text { Promise } F_{2}\end{array}$ & $\begin{array}{c}\text { Segregation } \\
\text { distortion analysis }\end{array}$ & $\begin{array}{c}\text { Transformation } \\
\text { amenability from } \\
\text { immature } \\
\text { embryos }\end{array}$ & $10(\operatorname{chr} 1-6 \mathrm{H})$ & $(H v N I R)$ & Hisano et al. 2016 [115] \\
\hline & $\begin{array}{l}\text { Full Pint } x \text { Golden } \\
\text { Promise DHs }\end{array}$ & $\begin{array}{c}\text { Segregation } \\
\text { distortion analysis }\end{array}$ & $\begin{array}{c}\text { Transformation } \\
\text { amenability from } \\
\text { immature } \\
\text { embryos }\end{array}$ & $3(\mathrm{chr} 2-3 \mathrm{H})$ & $\begin{array}{l}\text { HvBBM, } \\
\text { HvWUS2 }\end{array}$ & Hisano et al. 2017 [116] \\
\hline
\end{tabular}




\subsubsection{Dicot Crops}

The shoot regeneration capacity of tomato is believed to be inherited in a dominant way, but it is not clear how many genes are involved (Table 3). Analyzing a population obtained by crossing wild Lycopersicon peruvianum with cultivated L. esculentum plants using morphological and RFLP markers pinpointed a QTL near the middle of chromosome 3, designated $\mathrm{Rg}-1$, and proposed to act together with one or two other loci in the control of shoot regeneration from root explants [117]. Subsequently, the $R g-2$ allele from $L$. chilense was mapped to the same region and linked to an acid invertase gene [118]. More recently, interval mapping with two populations derived from L. esculentum and L. pennellii identified 6 QTLs on chromosomes 1, 3, 4, 7 and 8, underlying shoot regeneration from leaf disks and mapping of prior candidates $R g-2$ and LESK1 (a serine/threonine kinase upregulated during shoot induction), suggested that the QTL on chromosome 3 might be another allele of $R g-2$, which was dubbed $\mathrm{Rg}$-3 [119]. LESK1 was not located in a QTL but other regions contained serine/threonine kinases, histidine kinases, AP2/ERF TFs, cyclins, and MADS-box genes. Notably, only the two main QTLs on chromosomes 1 and 7 were found for all three investigated traits, and only the $R g-3$ locus overlapped with previous findings based on root explants, confirming the occurrence of conditional regeneration determinants in tomato. On the other hand, $\mathrm{Rg}-1$ appears to be a master regulator as it increases both shoot and root formation, rescuing the dual effects caused by the knockout of the DELLA protein PROCERA (PRO) and the specific phenotypes of auxin-resistant diageotropica (dgt) and lateral suppresser (ls) mutants, while overexpression of MOUSE EARS (ME) only increased shoot induction on SIM [120]. In cucumber, QTL mapping uncovered four loci on chromosomes 1, 3, and 6, explaining 9.7-16.6\% of the variation in cotyledon regeneration in RILs (Table 3) [121]. GWAS detected 18 SNPs in a region on chromosome 1 , underlying multiple media compositions, which were linked to three candidate genes including a homolog of Arabidopsis $\mathrm{J3}$ (a chaperone that regulates $\mathrm{H}^{+}$ATPases in the plasma membrane by inactivating PKS5, integrates flowering signals and causes ABA hypersensitivity and enlarged meristems when defective). This gene was upregulated in highly regenerable genotypes, and overexpression enhanced the performance of the recalcitrant RIL parent [121]. Composite interval mapping of the regeneration rate in microspore cultures of radish identified five QTLs and five corresponding candidate genes, homologous to PRC2 subunits and flavin-binding monooxygenases with a role in auxin biosynthesis and de novo root formation (Table 3) [122]. Finally, two QTLs were discovered for protoplast regeneration in broccoli [123], and three unlinked genes were proposed to control shoot regeneration from leaf explants of wild potato (Table 3) [124].

\subsubsection{Ornamentals and Commodity Crops}

Rapid multiplication by in vitro shoot regeneration is especially useful for ornamentals, such as roses, GWAS of which detected 88 SNPs for direct shoot organogenesis from petioles, including 20 that were shared between two traits and 12 that were linked to known candidates in Arabidopsis (Table 3) [125]. These were factors related to morphogenesis, epigenetic regulation, and hormone signaling, such as a GT2-like trihelix TF, an LRR receptor-like kinase, a RAP2.7-like ERF, a DNA methylation 3-like protein, a BIG auxin transporter, a GAI-like DELLA, a KNOTTED1-like 3 homeobox, and YAB2. When mapped to a strawberry genome, the QTLs fell into small clusters containing homologs of WUS, CUC1, SOMATIC EMBRYGENESIS RECEPTOR-LIKE KINASE 1 (SERK1), and RPK1. Sunflower, on the other hand, is an important crop for oil production, and because mass clonal propagation using cultured explants would facilitate genetic engineering, a RIL population has been developed to screen for molecular markers linked to shoot regeneration from cotyledon explants and somatic embryogenesis from epidermal layers [126,127]. This revealed transgressive segregation and identified 13 and 11 QTLs, explaining $52-67 \%$ and $48-89 \%$ of the respective traits, although no candidate genes were proposed (Table 3). Poplar is another valuable commodity crop (e.g., for timber, plywood, pulp, and paper) that has also been proposed as a model system for woody species. Association mapping of callus formation from parenchyma cells in 280 poplar genotypes uncovered 8 QTGs, and a transcriptional network indicated that these were coexpressed with a multitude of cell cycle components, as well as homologs 
of LBD16, LEC1E2, WUS, TSD1, and CLF (Table 3) [128]. Another recent study reported 83 loci linked to 275 QTGs underlying in vivo shoot traits in poplar [129].

Table 3. Nonexhaustive overview of QTL mapping studies on regeneration in dicot crops since 2000. The QTL and QTG columns respectively specify the number (and chromosomal position) of quantitative trait loci and highlight quantitative trait genes (plausible candidates are bracketed).

\begin{tabular}{|c|c|c|c|c|c|c|}
\hline Species & Population & Method & Phenotype(s) & $Q T L(s)$ & $Q T G(s)$ & Reference \\
\hline \multirow{2}{*}{$\begin{array}{l}\text { Lycopersicon } \\
\text { esculentum }\end{array}$} & $\begin{array}{l}\text { L. chilense } \times \text { KOT } \\
\qquad \mathrm{BC}_{1} \mathrm{~F}_{2}\end{array}$ & $\begin{array}{l}\text { Bulked } \\
\text { segregant } \\
\text { analysis }\end{array}$ & $\begin{array}{c}\text { Shoot } \\
\text { regeneration from } \\
\text { root explants }\end{array}$ & 1 (chr 3) & RG-2/INVCHI & Satoh et al. 2000 [118] \\
\hline & $\begin{array}{l}\text { S. pennellii } x \text { Anl27 } \\
\mathrm{F}_{2} \text { and } \mathrm{BC}_{1}\end{array}$ & $\begin{array}{l}\text { QTL interval } \\
\text { mapping }\end{array}$ & $\begin{array}{c}\text { Shoot } \\
\text { regeneration from } \\
\text { leaf disks }\end{array}$ & $\begin{array}{c}6(\mathrm{chr} 1,3,4,7 \\
\text { and } 8)\end{array}$ & $\begin{array}{l}R G-3,(L E S K 1, \\
\text { ESR1\&2) }\end{array}$ & Trujillo-Moya et al. 2011 [119] \\
\hline Cucumis sativus & $\begin{array}{l}9110 \text { Gt } x 9930 \\
\text { RILs and } 115 \text { core } \\
\text { accessions }\end{array}$ & $\begin{array}{l}\text { QTL interval } \\
\text { mapping } \\
\text { and GWAS }\end{array}$ & $\begin{array}{l}\text { Shoot } \\
\text { regeneration from } \\
\text { cotyledon } \\
\text { explants }\end{array}$ & 4 (chr 1, 3, and 6) & ATJ3 & Wang et al. 2018 [121] \\
\hline Raphanus sativus & GX71 x GX50 F 1 & $\begin{array}{l}\text { Composite } \\
\text { interval } \\
\text { mapping }\end{array}$ & $\begin{array}{c}\text { Somatic } \\
\text { embryogenesis } \\
\text { from microspore } \\
\text { cultures }\end{array}$ & $5(\operatorname{chr} 3,8$, and 9$)$ & $\begin{array}{c}\text { PRC2, } \\
\text { FLAVIN-BINDING } \\
\text { MONO-OXYGENASE } \\
\text { SET DOMAIN } \\
\text { PROTEIN } \\
\end{array}$ & E, Kim et al. 2020 [122] \\
\hline Brassica oleracea & $\begin{array}{c}\text { CGC 3-1 x } \\
\text { Daehnfelt 360-7 F }{ }_{2}\end{array}$ & $\begin{array}{l}\text { Simple } \\
\text { interval } \\
\text { mapping }\end{array}$ & $\begin{array}{c}\text { Shoot } \\
\text { regeneration from } \\
\text { protoplast-derived } \\
\text { calli }\end{array}$ & $2(-)$ & - & Holme et al. 2004 [123] \\
\hline Rosa sp. & 96 cultivars & GWAS & $\begin{array}{l}\text { Direct shoot } \\
\text { regeneration from } \\
\text { leaf petioles }\end{array}$ & 88 (chr 1 and 3-6) & $\begin{array}{c}\text { GT2-like, } \\
\text { RAP2.7-like, } \\
\text { MET3-like, } \\
\text { KNOX1-like 3, } \\
\text { ANP1-like, } \\
\text { GAI-like, YAB2, } \\
\text { BIG, WUS, } \\
\text { CUC1, SERK1, } \\
\text { RPK1,... }\end{array}$ & Nguyen et al. 2017 [125] \\
\hline \multirow{2}{*}{ Helianthus annuus } & $\begin{array}{c}\text { PAC- } 2 \times \text { RHA-266 } \\
\text { RILS }\end{array}$ & $\begin{array}{l}\text { Composite } \\
\text { interval } \\
\text { mapping }\end{array}$ & $\begin{array}{l}\text { Shoot } \\
\text { regeneration from } \\
\text { cotyledon } \\
\text { explants }\end{array}$ & $\begin{array}{c}13 \text { (chr } 2,6-9,15 \\
\text { and } 17)\end{array}$ & - & Flores Berrios et al. 2000a [127] \\
\hline & $\begin{array}{c}\text { PAC- } 2 \times \text { RHA- } 266 \\
\text { RILS }\end{array}$ & $\begin{array}{l}\text { Composite } \\
\text { interval } \\
\text { mapping }\end{array}$ & $\begin{array}{c}\text { Somatic } \\
\text { embryogenesis } \\
\text { from epidermal } \\
\text { layers } \\
\end{array}$ & $\begin{array}{r}11(\operatorname{chr} 1,3,4,6 \\
11,13 \text {, and } 15-17)\end{array}$ & - & Flores Berrios et al. 2000b [126] \\
\hline Populus trichocarpa & 280 genotypes & $\begin{array}{l}\text { GWAS and } \\
\text { co-expression } \\
\text { analysis }\end{array}$ & $\begin{array}{c}\text { Callus formation } \\
\text { from parenchyma } \\
\text { cells }\end{array}$ & $\begin{array}{c}8(\operatorname{chr} 3,4,6,8,9 \\
12,15, \text { and } 18)\end{array}$ & $\begin{array}{c}\text { SOK1, MAPK3, } \\
\text { SCR-like, } \\
\text { RALF-like, WUS, } \\
\text { LBD16, LEC1E2, } \\
\text { CLF, TSD1,... } \\
\end{array}$ & Tuskan et al. 2018 [128] \\
\hline
\end{tabular}

\section{Other Sources of Regenerative Variation}

\subsection{Epigenetic and Transcriptional Variation}

Because many key histone modifiers and DNA methylation enzymes, as well as their target marks and genes, are differentially regulated during incubation on CIM and SIM, epigenetics constitute an important regulatory layer of de novo shoot organogenesis [7,40,53,130]. Moreover, several such factors were suggested to underpin regeneration QTLs, and many important TFs and meristem determinants contain SNPs in the promoter region rather that the gene body [80], indicating that sequence variation in the epigenetic machinery and corresponding transcriptional changes might be preferred for fine-tuning gene activity over alterations in protein conformation. In turn, this implies that natural epigenomic and transcriptomic variation could be at the base of regenerative differences. With respect to this, it is important to note that genome-wide methylation patterns in Arabidopsis can be stably inherited over generations and are subject to selection in the context of rapid evolutionary responses [131-133]. Accordingly, the methylomes of 1028 natural accessions are highly variable, and many loci are polyepiallelic, meaning that they can be either unmethylated, show transposable element (TE)-like methylation (teM; mCG, $\mathrm{mCHG}$, or $\mathrm{mCHH}$ linked to transcriptional repression), or gene body methylation (gbM; mCG normally coupled to constitutive gene expression, but also promoting the development of silenced teM alleles) $[134,135]$. Whereas TEs and sequence repeats are consistently 
and densely methylated by small interfering RNA (siRNA)-directed maintenance [133,136], the extent of $\mathrm{gbM}$, in particular, differs across 725 strains and is inversely correlated with heterochromatin methylation levels through a feedback loop involving CMT3, H3K9me2, and histone turnover [137]. On the other hand, teM interacts with allele-specific gene imprinting, and it has been suggested that siRNAs contribute to epigenetic differences between strains as well $[138,139]$. GWAS on differential methylation highlighted many prior candidates, such as CMT2, AGO1E9, and NUCLEAR RNA POLYMERASE D1B (NRPD1B; involved in RNA-directed DNA methylation), while the observation that eQTLs and epi-eQTLs (respectively SNPs and differentially methylated regions (or DMRs) underlying gene expression) were often found at transcription start sites indicates that the general silencing effect of methylation is mediated by altered TF binding [134]. This also follows from the large overlap between DMRs and the (epi)cistrome, although eQTLs and epi-eQTLs appear to target largely distinct TF sets (e.g., CUC2 binding sites were specifically enriched at eQTLs). Notably, epiRILs (RILs with similar DNA sequences but diverging methylomes) show comparable phenotypic inheritance as RILs or natural accessions [131], confirming that epigenetic variation contributes to environmental adaptation [132,134]. These epiRILs have also been used to map DMRs explaining variability in plant growth, morphology, and plasticity, revealing around 20 epigenetic QTLs, of which 8 had pleiotropic effects (i.e., these were required for multiple traits under different conditions) [140]. Hence, epiRILs and methylome-wide association studies (MWAS) provide interesting future prospects for elucidating additional regulatory layers of shoot regeneration [141]. In addition to DNA methylation, it was reported that H3K27me3 levels show allele-specific inheritance, but only a few targets differ between Col and Ler strains, which has been coupled to the spreading of repressive heterochromatin marks (e.g., H3K9me2) from nearby TE insertions [142]. Although the underlying mechanisms are not straightforward, variable methylation and histone modification patterns amplify transcriptomic variation, underlined by differential expression of 22,085 genes among 998 natural accessions, which further drives phenotypic variation and adaption $[134,135,137,142]$. Transcriptome-wide association studies (TWAS) could be applied to identify eQTLs for de novo shoot organogenesis.

\subsection{Source of the Explant and Hormone Responsivity}

Explant age, physiological state, and source tissue (root, hypocotyl, leaf, petiole, inflorescence, microspore, etc.) determine the efficiency of regeneration, concordant with different medium requirements for callus, root, and shoot formation from root, hypocotyl, and leaf explants of diverse ecotypes $[11,82,84,143]$. Given the plasticity of plant morphology and inaccuracy of human work, it is impossible to ensure that such variables are perfectly uniform in the explant population. After all, many growth and developmental traits such as rosette shape, leaf expansion, and flowering time are subject to natural variation, and at any given time, different plants are at distinct developmental stages [92,144,145]. Generally, juvenile explants regenerate better than adult organs, and it has been suggested that the differential plasticity of various tissues is partly determined by changes in hormone responsivity, which may be mediated by IRE genes $[10,146]$. For instance, adventitious rooting in pea is negatively impacted by the switch from vegetative to reproductive growth, which was attributed to altered auxin homeostasis and delayed JA accumulation [147]. Accordingly, exogenous auxin application and increased cytokinin supply can respectively rescue reduced root and shoot regeneration from older Arabidopsis leaves [16,74]. Intriguingly, it was shown that root hormone concentrations differ between natural accessions, which was especially true for cytokinin ribosides and glucosides [148]. While moderate alterations in auxin levels and responsivity were correlated with complex root architecture, increased ethylene sensitivity was observed in poorly regenerating ecotypes [149]. Variable hormone homeostasis could also explain part of the large fluctuations in physiological and transcriptional auxin responses among strains, as these were not the result of SNPs in signaling components [150]. Furthermore, tissue-specific methylome and transcriptome patterns caused by spatiotemporal variation in endogenous hormone concentrations and cell division rates contribute to cellular heterogeneity in the callus, in turn allowing some green foci to form complete 
shoots when others halt their development [20]. Several additional factors have been put forward as determinants of regenerative variability within individual plants, including expression gradients of PLT2 underlying lower repair potential at the proximal root end [151], an intrinsic timer involving miR156 and SPL9 that is responsible for progressively declining shoot regeneration in older plants [74] and the abundance of pre-existing adult stem cells in the explant [11].

To determine whether the capacity for shoot formation from root explants is linked to other characteristics of the parent plant, we performed a correlation meta-analysis between 16 regeneration traits in 170 Arabidopsis strains [80] and 383 public phenotypes from the AraPheno database that were scored in at least 50 overlapping accessions (Figure 2) [152,153]. In total, 78 of these were associated to at least one regeneration trait (at a false discovery rate (FDR) $<0.3$ ), and 28 yielded a Spearman's rho with an absolute value greater than 0.3 and an FDR below $10 \%$. Contrary to previous reports, we detected significant positive correlations between shoot numbers, shoot primordia, undefined structures, and green callus area under two regeneration protocols, differing in the age of source plants, applied light spectrum, and external cytokinin concentration [81]. Root-like structures were comparable across protocols but form a separate category from the other traits. Intriguingly, the majority of linked public phenotypes relate to the endemic climate of the accessions under study [154], suggesting a link between regeneration and adaptation. For instance, the average monthly precipitation at the origin of strains in November and December (clim-prec11\&12) is positively correlated to regeneration and especially to shoot primordia under protocol a, whereas potential and actual evapotranspiration in January (clim-pet1 and clim-pet1) are mainly connected to shoot characteristics under protocol b. Winter temperatures (e.g., clim-tmax from November through February and clim-tmin for December) show slightly positive links with shoot and callus induction, but they are inversely related to root traits, which further benefit from the inclusion of June or July in the growing season (clim-gs6\&7). Root-like structures are also associated with lateral root densities and length of the basal rhizosphere under salt stress (e.g., LRDpMR0\&125 and Basal0\&75) [155]. Finally, shoot regeneration is negatively correlated to external characteristics of source plants, including their diameter after 5 weeks and the occurrence of rolled leaves after 8 weeks [145], as well as the concentration of metabolites with a mass-over-charge ratio of either 130 or 216 and a respective retention time of 666 or $665 \mathrm{~s}$ [156], suggesting a possibility for predictive models.

\subsection{Environmental Influences}

It is likely that part of the regenerative variation among explants from the same individual or subspecies can be attributed to fluctuations in environmental conditions, such as light, temperature, osmotic stress, and medium composition. For instance, it was found that variable light exposure of cotyledon explants during the first 5 days after excision affects shoot regeneration in Arabidopsis, and this response was different in 4 accessions [157]. More specifically, high fluorescent light intensities and early dark-light shifts impeded callus formation and regeneration, which involved the UV-A photoreceptor CRY1 and photo-oxidative damage caused by ROS accumulation. On the other hand, 2-24 h of darkness after injury and ROS quenching by xanthophylls improved shoot regeneration. The red/far-red receptors PHYTOCHROME A\&B (PHYA\&B) and the downstream TF ELONGATED HYPOCOTYL 5 (HY5) suppressed light inhibition by upregulating a chalcone synthase for the production of photoprotective anthocyanin pigments, which may be further enhanced by cytokinin. HY5 also mitigated the inhibitory effect of polar auxin transport, while ethylene respectively had positive and negative impacts in darkness and light [157]. Notably, calli were found to regenerate better under continuous low light exposure than using either constant high light, a 16/8 hour light-dark cycle, or complete darkness [158]. Low light intensity was also reported to promote shoot proliferation in cotton [159], and appropriate ratios of blue and red light can enhance regeneration traits in different poplar genotypes [160]. Curiously, the effects of photoperiod, light quantity, and spectrum are not always consistent between species as light is required for shoot morphogenesis in petunia [161], whereas it is not essential in tomato (although altered light-dark cycles do affect direct shoot regeneration) [162]. The use of 
light-emitting diodes (LEDs) could provide a cost-effective solution to address specific requirements for light intensity and wavelength in different systems [6]. Similar paradoxical observations were made for temperature effects, as both a 3-day cold pretreatment and incubation at high temperatures can increase callus formation in Arabidopsis, indicating the existence of an optimum for every system [44,158]. Extended cold treatments of 3-5 weeks at $3{ }^{\circ} \mathrm{C}$ could also overcome growth arrest in subcultures of crosses between peach and almond trees [163]. Optimal conditions for osmotic-stress-induced somatic embryogenesis from shoot tips and leaf buds in Arabidopsis differed between ecotypes [13], and the addition of sorbitol to the culture medium promoted shoot organogenesis from seed-derived callus in rice [164]. The latter relied on polar auxin transport, and highly regenerable calli were characterized by high sugar content and elevated transcript levels of invertase, sucrose transporter, OsPIN1, and LATE EMBRYOGENESIS ABUNDANT 1 (OsLEA1) genes, implicating interaction between auxin, ABA, and carbohydrate metabolism for osmotic stress regulation in callus. Notably, constitutive osmotic stress in plastids of Arabidopsis MscS-like mechanosensitive ion channel (msl2 msl3) mutants leads to callus development at the shoot apex, involving perception of elevated cytokinin levels by AHK2, upregulation of WUS, and downregulation of ARR7E15 [165]. A second independent pathway underlying this phenomenon required ROS accumulation in the SAM and increased ABA biosynthesis, which mediated retrograde signaling via downstream factors ABA INSENSITIVE 4 (ABI4) and GENOMES UNCOUPLED 1 (GUN1) to fine-tune proliferation. In Lathyrus, on the other hand, polyethylene glycol (PEG)-induced osmotic stress reduced the multiplication rate and vigor of regenerated shoots [166], and $\mathrm{NaCl}$ had opposite effects on calli of Arabidopsis and Thellungiella [167]. Finally, parameters related to the culture medium, such as nutrients (e.g., carbon source, minerals, and vitamins), plant growth regulators, solidifying agents, and $\mathrm{pH}$ may be regarded as constants within a particular protocol, but they can add to variation between (sub)species and tissues $[143,164,168]$. In Arabidopsis, leaf or root explants respectively prefer sucrose or glucose [143], cytokinin omission benefits protoplast development [169], activated charcoal promotes regeneration from anther-derived cultures [170], and supplementing SIM with ABA improves de novo shoot formation from roots [171].

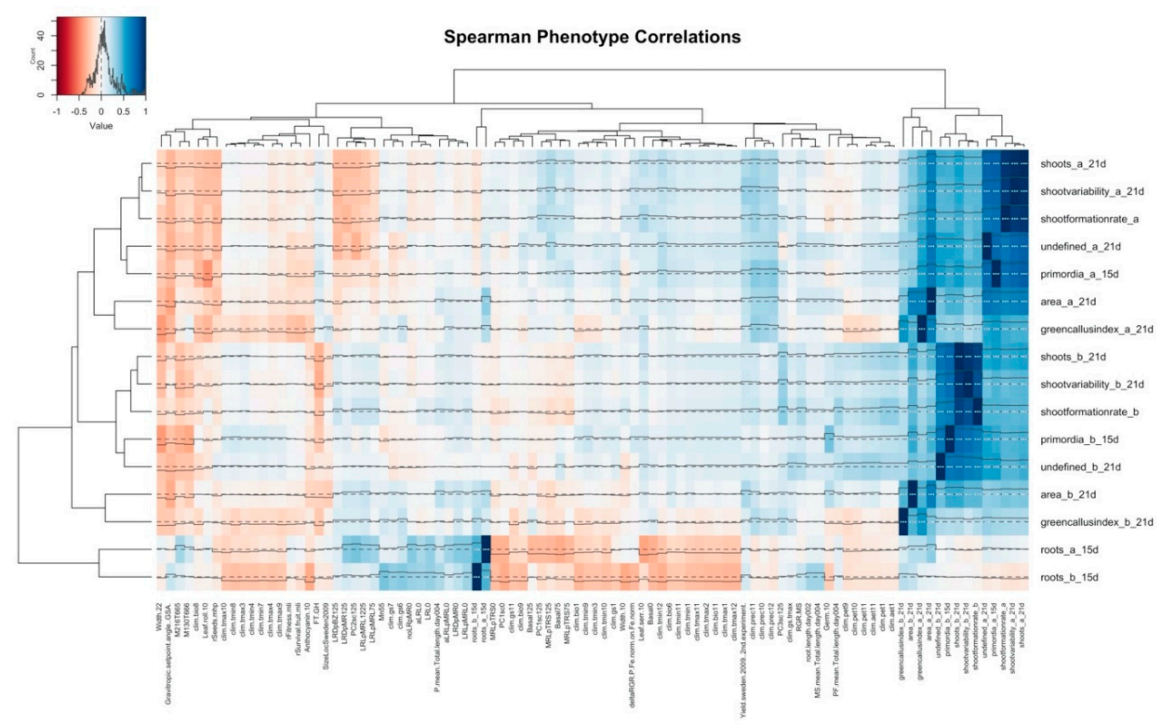

Figure 2. Spearman's rho for pairwise comparisons between 16 regeneration traits in 170 Arabidopsis accessions [80] and 78 public phenotypes from AraPheno scored in at least 50 of these accessions and was significantly associated to at least one regeneration trait (FDR < 0.3) [153]. Dendrograms are based on Euclidean distances, and the legend in the upper left corner shows the color gradient and histogram of correlation coefficients. The value of the latter is also reflected by grey trace lines in the main plot. Significance is based on FDR-adjusted $p$-values from Spearman's test $(.=p \leq 0.1$, ${ }^{*}=p \leq 0.05,{ }^{* *}=p \leq 0.01,{ }^{* *}=p \leq 0.001$ ). Accurate descriptions of all phenotypes can be found at https://arapheno.1001genomes.org/phenotypes. 


\section{Implications and Future Perspectives}

Taken together, regeneration is a highly complex trait controlled by multiple intertwined regulatory layers that are all subject to variation, making it difficult to predict in vitro culture responses. Although significant progress has been made in elucidating the molecular framework and many potential QTLs have been identified, only a subset was mapped to specific genes. These can be divided into conditional factors and master regulators, posing the question of which established meristem determinants have specific roles in Arabidopsis and which ones are conserved, such as WUSCHEL-RELATED HOMEOBOX genes, AP2/ERF transcription factors like BBM, and receptor-like protein kinases. Knowledge of which genes are rate-limiting in a particular system can be used to overcome recalcitrance or improve the regeneration efficiency through genetic engineering. In order to avoid deleterious side-effects, the best strategies for ectopic gene activation involve the use of tissue-specific or inducible promoters (e.g., incorporating dexamethasone or estradiol-responsive elements), transient expression (e.g., based on cotransfection and segregation or inefficient T-strand processing in Agrobacterium-mediated methods), or excision of genes at a later stage (e.g., using FLP or CRE recombinases) [172]. Adding morphogenic genes to expression cassettes for transformation (rather than producing stable transgenic germplasms through conventional methods such as a floral dip) also facilitates the selection of transformed cells as these have a regenerative advantage over wild-type tissues. Conversely, RNA interference could be exploited to temporarily silence suppressors of organogenesis (either by introducing chemical-inducible constructs that express antisense or hairpin templates or by transient delivery of double-stranded RNA through agroinfiltration or infection with recombinant viral vectors) because permanent gene knockouts can be detrimental to normal development and they are hard to establish in polyploid crops [173-175]. For example, cytokinin hypersensitivity caused by the RNAi knockdown of CARBOXYL-TERMINAL DOMAIN PHOSPHATASE-LIKE 4 (CPL4) was already shown to boost de novo shoot organogenesis from root explants in Arabidopsis [176]. Next, further investigation is required to probe the role of epialleles in shaping phenotypic variation. Recent advances in sequencing technologies, including RNA-seq, ChIP-seq, and MethylC-seq, along with the availability of more than 1000 genomes, methylomes and transcriptomes for natural Arabidopsis accessions, will help to shed light on this matter by enabling accurate association of genetic, epigenetic, and transcriptional effects underlying the differential organogenic potential between and within species. Ultimately, this will contribute to the development of selectable markers to screen for highly regenerable cultivars, while a better understanding of how rate-limiting factors interact with the environment could empower targeted design of protocols for biotechnology applications in crops. Machine learning algorithms provide a complementary prospect for fine-tuning protocol development, as they allow to predict optimal requirements in terms of incubation conditions, plant growth regulators, explant source, and genotype, without the need for large-scale, time-consuming, and costly experimental trials. The potential of this approach is illustrated by recent reports on the application of artificial neural networks to model and augment somatic embryogenesis and shoot proliferation in Chrysanthemum and shoot regeneration in wheat by altering medium composition [177-179]. Similar strategies have been used to increase the production of therapeutic metabolites from in vitro cultures of Swertia paniculata and Bryophyllum [180,181]. Advanced treatments based on antibiotics, electric currents, and nanoparticles could further help to overcome recalcitrance [6]. Finally, further study is required to explain how regeneration might be linked to climate adaptation. 
Author Contributions: Writing—original draft preparation and visualization, R.L.; writing—review and editing, D.G. All authors have read and agreed to the published version of the manuscript.

Funding: This research was funded by the Research Foundation Flanders (FWO), application numbers 1S48517N and G094619N.

Acknowledgments: We thank Keiko Sugimoto for suggesting a correlation meta-analysis of regeneration traits.

Conflicts of Interest: The authors declare no conflict of interest and the funders had no role in the writing of the manuscript or in the decision to publish the results.

\section{References}

1. Pulianmackal, A.J.; Kareem, A.V.K.; Durgaprasad, K.; Trivedi, Z.B.; Prasad, K. Competence and regulatory interactions during regeneration in plants. Front. Plant Sci. 2014, 5, 142. [CrossRef] [PubMed]

2. Xu, L.; Huang, H. Genetic and Epigenetic Controls of Plant Regeneration, 1st ed.; Elsevier Inc.: Amsterdam, The Netherlands, 2014; Volume 108, ISBN 9780123914989.

3. Perianez-Rodriguez, J.; Manzano, C.; Moreno-Risueno, M.A. Post-embryonic organogenesis and plant regeneration from tissues: Two sides of the same coin? Front. Plant Sci. 2014, 5, 219. [CrossRef] [PubMed]

4. Motte, H.; Vereecke, D.; Geelen, D.; Werbrouck, S. The molecular path to in vitro shoot regeneration. Biotechnol. Adv. 2014, 32, 107-121. [CrossRef] [PubMed]

5. Bhatia, S.; Bera, T. Somatic Embryogenesis and Organogenesis; Elsevier Inc.: Amsterdam, The Netherlands, 2015; ISBN 9780128024980.

6. Bidabadi, S.S.; Mohan Jain, S. Cellular, molecular, and physiological aspects of in vitro plant regeneration. Plants 2020, 9, 702. [CrossRef] [PubMed]

7. Ikeuchi, M.; Favero, D.S.; Sakamoto, Y.; Iwase, A.; Coleman, D.; Rymen, B.; Sugimoto, K. Molecular Mechanisms of Plant Regeneration. Annu. Rev. Plant Biol. 2019, 70, 377-406. [CrossRef] [PubMed]

8. Horstman, A.; Bemer, M.; Boutilier, K. A transcriptional view on somatic embryogenesis. Regeneration 2017, 4, 201-216. [CrossRef] [PubMed]

9. Nishihama, R.; Ishizaki, K.; Hosaka, M.; Matsuda, Y.; Kubota, A.; Kohchi, T. Phytochrome-mediated Regulation of Cell Division and Growth During Regeneration and Sporeling Development in the Liverwort Marchantia Polymorpha. J. Plant Res. 2015, 128. [CrossRef]

10. Ikeuchi, M.; Ogawa, Y.; Iwase, A.; Sugimoto, K. Plant regeneration: Cellular origins and molecular mechanisms. Development 2016, 143, 1442-1451. [CrossRef]

11. Kareem, A.; Radhakrishnan, D.; Sondhi, Y.; Aiyaz, M.; Roy, M.V.; Sugimoto, K.; Prasad, K. De novo assembly of plant body plan: A step ahead of Deadpool. Regeneration 2016, 3, 182-197. [CrossRef]

12. Méndez-Hernández, H.A.; Ledezma-Rodríguez, M.; Avilez-Montalvo, R.N.; Juárez-Gómez, Y.L.; Skeete, A.; Avilez-Montalvo, J.; De-La-Peña, C.; Loyola-Vargas, V.M. Signaling overview of plant somatic embryogenesis. Front. Plant Sci. 2019, 10, 1-15. [CrossRef]

13. Ikeda-Iwai, M.; Umehara, M.; Satoh, S.; Kamada, H. Stress-induced somatic embryogenesis in vegetative tissues of Arabidopsis thaliana. Plant J. 2003, 34, 107-114. [CrossRef] [PubMed]

14. Nic-Can, G.I.; Avilez-Montalvo, J.R.; Aviles-Montalvo, R.N.; Márquez-López, R.E.; Mellado-Mojica, E.; Galaz-Ávalos, R.M.; Loyola-Vargas, V.M. The relationship between stress and somatic embryogenesis. In Somatic Embryogenesis: Fundamental Aspects and Applications; Springer: Berlin/Heidelberg, Germany, 2016; pp. 121-170, ISBN 9783319337050.

15. $\mathrm{Xu}, \mathrm{L}$. De novo root regeneration from leaf explants: Wounding, auxin, and cell fate transition. Curr. Opin. Plant Biol. 2018, 41, 39-45. [CrossRef] [PubMed]

16. Chen, X.; Qu, Y.; Sheng, L.; Liu, J.; Huang, H.; Xu, L. A simple method suitable to study de novo root organogenesis. Front. Plant Sci. 2014, 5, 208. [CrossRef] [PubMed]

17. Liu, J.; Sheng, L.; Xu, Y.; Li, J.; Yang, Z.; Huang, H.; Xu, L. WOX11 and 12 are involved in the first-step cell fate transition during de novo root organogenesis in Arabidopsis. Plant Cell 2014, 26, 1081-1093. [CrossRef]

18. Valvekens, D.; Van Montagu, M.; Van Lijsebettens, M. Agrobacterium tumefaciens-mediated transformation of Arabidopsis thaliana root explants by using kanamycin selection. Proc. Natl. Acad. Sci. USA 1988, 85, 5536-5540. [CrossRef]

19. Shin, J.; Bae, S.; Seo, P.J. De novo shoot organogenesis during plant regeneration. J. Exp. Bot. 2020, 71, 63-72. [CrossRef] 
20. Radhakrishnan, D.; Kareem, A.; Durgaprasad, K.; Sreeraj, E.; Sugimoto, K.; Prasad, K. Shoot regeneration: A journey from acquisition of competence to completion. Curr. Opin. Plant Biol. 2018, 41, 23-31. [CrossRef]

21. Tian, X.; Zhang, C.; Xu, J. Control of Cell Fate Reprogramming Towards de Novo Shoot Organogenesis. Plant Cell Physiol. 2018, 59, 708-714. [CrossRef]

22. Sang, Y.L.; Cheng, Z.J.; Zhang, X.S. Plant stem cells and de novo organogenesis. New Phytol. 2018, 218, 1334-1339. [CrossRef]

23. Su, Y.H.; Zhang, X.S. The Hormonal Control of Regeneration in Plants. In Current Topics in Developmental Biology; Elsevier: Amsterdam, The Netherlands, 2014; Volume 108, pp. 35-69.

24. Schaller, G.E.; Bishopp, A.; Kieber, J.J. The yin-yang of hormones: Cytokinin and auxin interactions in plant development. Plant Cell 2015, 27, 44-63. [CrossRef]

25. Cheng, Z.J.; Wang, L.; Sun, W.; Zhang, Y.; Zhou, C.; Su, Y.H.; Li, W.; Sun, T.T.; Zhao, X.Y.; Li, X.G.; et al. Pattern of auxin and cytokinin responses for shoot meristem induction results from the regulation of cytokinin biosynthesis by AUXIN RESPONSE FACTOR3. Plant Physiol. 2013, 161, 240-251. [CrossRef] [PubMed]

26. Zhang, T.-Q.; Lian, H.; Zhou, C.-M.; Xu, L.; Jiao, Y.; Wang, J.-W. A Two-Step Model for de Novo Activation of WUSCHEL during Plant Shoot Regeneration. Plant Cell Online 2017, 29, 1073-1087. [CrossRef] [PubMed]

27. Iwase, A.; Mita, K.; Nonaka, S.; Ikeuchi, M.; Koizuka, C.; Ohnuma, M.; Ezura, H.; Imamura, J.; Sugimoto, K. WIND1-based acquisition of regeneration competency in Arabidopsis and rapeseed. J. Plant Res. 2015, 128, 389-397. [CrossRef] [PubMed]

28. Ikeuchi, M.; Iwase, A.; Rymen, B.; Lambolez, A.; Kojima, M.; Takebayashi, Y.; Heyman, J.; Watanabe, S.; Seo, M.; De Veylder, L.; et al. Wounding triggers callus formation via dynamic hormonal and transcriptional changes. Plant Physiol. 2017, 175, 1158-1174. [CrossRef]

29. Iwase, A.; Mitsuda, N.; Koyama, T.; Hiratsu, K.; Kojima, M.; Arai, T.; Inoue, Y.; Seki, M.; Sakakibara, H.; Sugimoto, K.; et al. The AP2/ERF transcription factor WIND1 controls cell dedifferentiation in arabidopsis. Curr. Biol. 2011, 21, 508-514. [CrossRef]

30. Iwase, A.; Ohme-Takagi, M.; Sugimoto, K. WIND1: A key molecular switch for plant cell dedifferentiation. Plant Signal. Behav. 2011, 6, 1943-1945. [CrossRef]

31. Iwase, A.; Harashima, H.; Ikeuchi, M.; Rymen, B.; Ohnuma, M.; Komaki, S.; Morohashi, K.; Kurata, T.; Nakata, M.; Ohme-Takagi, M.; et al. WIND1 Promotes Shoot Regeneration through Transcriptional Activation of ENHANCER OF SHOOT REGENERATION1 in Arabidopsis. Plant Cell 2017, 29, 54-69. [CrossRef]

32. Rymen, B.; Kawamura, A.; Lambolez, A.; Inagaki, S.; Takebayashi, A.; Iwase, A.; Sakamoto, Y.; Sako, K.; Favero, D.S.; Ikeuchi, M.; et al. Histone acetylation orchestrates wound-induced transcriptional activation and cellular reprogramming in Arabidopsis. Commun. Biol. 2019, 2, 1-15. [CrossRef]

33. Shin, J.; Seo, P.J. Varying auxin levels induce distinct pluripotent states in callus cells. Front. Plant Sci. 2018, 871, 1-4. [CrossRef]

34. Ikeuchi, M.; Sugimoto, K.; Iwase, A. Plant callus: Mechanisms of induction and repression. Plant Cell 2013, 25, 3159-3173. [CrossRef]

35. Che, P.; Lall, S.; Howell, S.H. Developmental steps in acquiring competence for shoot development in Arabidopsis tissue culture. Planta 2007, 226, 1183-1194. [CrossRef] [PubMed]

36. Atta, R.; Laurens, L.; Boucheron-Dubuisson, E.; Guivarc'h, A.; Carnero, E.; Giraudat-Pautot, V.; Rech, P.; Chriqui, D. Pluripotency of Arabidopsis xylem pericycle underlies shoot regeneration from root and hypocotyl explants grown in vitro. Plant J. 2009, 57, 626-644. [CrossRef] [PubMed]

37. Duclercq, J.; Sangwan-Norreel, B.; Catterou, M.; Sangwan, R.S. De novo shoot organogenesis: From art to science. Trends Plant Sci. 2011, 16, 597-606. [CrossRef] [PubMed]

38. Shang, B.; Xu, C.; Zhang, X.; Cao, H.; Xin, W.; Hu, Y. Very-long-chain fatty acids restrict regeneration capacity by confining pericycle competence for callus formation in Arabidopsis. Proc. Natl. Acad. Sci. USA 2016, 113, 5101-5106. [CrossRef]

39. Sugimoto, K.; Jiao, Y.; Meyerowitz, E.M. Arabidopsis regeneration from multiple tissues occurs via a root development pathway. Dev. Cell 2010, 18, 463-471. [CrossRef]

40. Xu, K.; Liu, J.; Fan, M.; Xin, W.; Hu, Y.; Xu, C. A genome-wide transcriptome profiling reveals the early molecular events during callus initiation in Arabidopsis multiple organs. Genomics 2012, 100, 116-124. [CrossRef]

41. Fan, M.; Xu, C.; Xu, K.; Hu, Y. LATERAL ORGAN BOUNDARIES DOMAIN transcription factors direct callus formation in Arabidopsis regeneration. Cell Res. 2012, 22, 1169-1180. [CrossRef] 
42. Lee, K.; Park, O.S.; Seo, P.J. Arabidopsis ATXR2 deposits H3K36me3 at the promoters of LBD genes to facilitate cellular dedifferentiation. Sci. Signal. 2017, 10. [CrossRef]

43. Lee, K.; Park, O.-S.; Seo, P.J. JMJ30-mediated demethylation of H3K9me3 drives tissue identity changes to promote callus formation in Arabidopsis. Plant J. 2018, 95, 961-975. [CrossRef]

44. Lee, K.; Seo, P.J. High-temperature promotion of callus formation requires the BIN2-ARF-LBD axis in Arabidopsis. Planta 2017, 246, 797-802. [CrossRef]

45. Liu, H.; Ma, X.; Han, H.N.; Hao, Y.J.; Zhang, X.S. AtPRMT5 Regulates Shoot Regeneration through Mediating Histone H4R3 Dimethylation on KRPs and Pre-mRNA Splicing of RKP in Arabidopsis. Mol. Plant 2016, 9, 1634-1646. [CrossRef] [PubMed]

46. Xu, C.; Cao, H.; Xu, E.; Zhang, S.; Hu, Y. Genome-Wide Identification of Arabidopsis LBD29 Target Genes Reveals the Molecular Events behind Auxin-Induced Cell Reprogramming during Callus Formation. Plant Cell Physiol. 2018, 59, 749-760. [CrossRef] [PubMed]

47. Xu, C.; Cao, H.; Zhang, Q.; Wang, H.; Xin, W.; Xu, E.; Zhang, S.; Yu, R.; Yu, D.; Hu, Y. Control of auxin-induced callus formation by bZIP59-LBD complex in Arabidopsis regeneration. Nat. Plants 2018, 4, 108-115. [CrossRef] [PubMed]

48. Buechel, S.; Leibfried, A.; To, J.P.C.; Zhao, Z.; Andersen, S.U.; Kieber, J.J.; Lohmann, J.U. Role of A-type Arabidopsis Response Regulators in meristem maintenance and regeneration. Eur. J. Cell Biol. 2010, 89, 279-284. [CrossRef]

49. Liu, Z.; Li, J.; Wang, L.; Li, Q.; Lu, Q.; Yu, Y.; Li, S.; Bai, M.-y.; Hu, Y.; Xiang, F. Repression of callus initiation by the miRNA-directed interaction of auxin-cytokinin in Arabidopsis thaliana. Plant J. 2016, 87, 391-402. [CrossRef]

50. Kim, J.; Yang, W.; Forner, J.; Lohmann, J.U.; Noh, B.; Noh, Y. Epigenetic reprogramming by histone acetyltransferase HAG1/AtGCN5 is required for pluripotency acquisition in Arabidopsis. EMBO J. 2018, 37, 1-16. [CrossRef]

51. Kareem, A.; Durgaprasad, K.; Sugimoto, K.; Du, Y.; Pulianmackal, A.J.; Trivedi, Z.B.; Abhayadev, P.V.; Pinon, V.; Meyerowitz, E.M.; Scheres, B.; et al. PLETHORA genes control regeneration by a two-step mechanism. Curr. Biol. 2015, 25, 1017-1030. [CrossRef]

52. Liu, J.; Hu, X.; Qin, P.; Prasad, K.; Hu, Y.; Xu, L. The WOX11-LBD16 Pathway Promotes Pluripotency Acquisition in Callus Cells during de Novo Shoot Regeneration in Tissue Culture. Plant Cell Physiol. 2018, 59, 734-743. [CrossRef]

53. He, C.; Chen, X.; Huang, H.; Xu, L. Reprogramming of H3K27me3 Is Critical for Acquisition of Pluripotency from Cultured Arabidopsis Tissues. PLoS Genet. 2012, 8, 1-13. [CrossRef]

54. Lee, K.; Park, O.S.; Jung, S.J.; Seo, P.J. Histone deacetylation-mediated cellular dedifferentiation in Arabidopsis. J. Plant Physiol. 2016, 191, 95-100. [CrossRef]

55. Lafos, M.; Kroll, P.; Hohenstatt, M.L.; Thorpe, F.L.; Clarenz, O.; Schubert, D. Dynamic regulation of H3K27 trimethylation during Arabidopsis differentiation. PLoS Genet. 2011, 7, e1002040. [CrossRef] [PubMed]

56. Ishihara, H.; Sugimoto, K.; Tarr, P.T.; Temman, H.; Kadokura, S.; Inui, Y.; Sakamoto, T.; Sasaki, T.; Aida, M.; Suzuki, T.; et al. Primed histone demethylation regulates shoot regenerative competency. Nat. Commun. 2019, 10, 1786. [CrossRef]

57. Shemer, O.; Landau, U.; Candela, H.; Zemach, A.; Eshed Williams, L. Competency for shoot regeneration from Arabidopsis root explants is regulated by DNA methylation. Plant Sci. 2015, 238, 251-261. [CrossRef] [PubMed]

58. Sugimoto, K.; Gordon, S.P.; Meyerowitz, E.M. Regeneration in plants and animals: Dedifferentiation, transdifferentiation, or just differentiation? Trends Cell Biol. 2011, 21, 212-218. [CrossRef] [PubMed]

59. Rosspopoff, O.; Chelysheva, L.; Saffar, J.; Lecorgne, L.; Gey, D.; Caillieux, E.; Colot, V.; Roudier, F.; Hilson, P.; Berthomé, R.; et al. Direct conversion of root primordium into shoot meristem relies on timing of stem cell niche development. Development 2017, 144, 1187-1200. [CrossRef]

60. Gordon, S.P.; Heisler, M.G.; Reddy, G.V.; Ohno, C.; Das, P.; Meyerowitz, E.M. Pattern formation during de novo assembly of the Arabidopsis shoot meristem. Development 2007, 134, 3539-3548. [CrossRef]

61. Ikeda, Y.; Banno, H.; Niu, Q.W.; Howell, S.H.; Chua, N.H. The ENHANCER of SHOOT REGENERATION 2 gene in Arabidopsis regulates CUP-SHAPED COTYLEDON 1 at the transcriptional level and controls cotyledon development. Plant Cell Physiol. 2006, 47, 1443-1456. [CrossRef] 
62. Takeda, S.; Hanano, K.; Kariya, A.; Shimizu, S.; Zhao, L.; Matsui, M.; Tasaka, M.; Aida, M. CUP-SHAPED COTYLEDON1 transcription factor activates the expression of LSH4 and LSH3, two members of the ALOG gene family, in shoot organ boundary cells. Plant J. 2011, 66, 1066-1077. [CrossRef]

63. Dai, X.; Liu, Z.; Qiao, M.; Li, J.; Li, S.; Xiang, F. ARR12 promotes de novo shoot regeneration in Arabidopsis thaliana via activation of WUSCHEL expression. J. Integr. Plant Biol. 2017, 59, 747-758. [CrossRef]

64. Meng, W.J.; Cheng, Z.J.; Sang, Y.L.; Zhang, M.M.; Rong, X.F.; Wang, Z.W.; Tang, Y.Y.; Zhang, X.S. Type-B ARABIDOPSIS RESPONSE REGULATORs Specify the Shoot Stem Cell Niche by Dual Regulation of WUSCHEL. Plant Cell 2017, 29, 1357-1372. [CrossRef]

65. Zubo, Y.O.; Blakley, I.C.; Yamburenko, M.V.; Worthen, J.M.; Street, I.H.; Franco-Zorrilla, J.M.; Zhang, W.; Hill, K.; Raines, T.; Solano, R.; et al. Cytokinin induces genome-wide binding of the type-B response regulator ARR10 to regulate growth and development in Arabidopsis. Proc. Natl. Acad. Sci. USA 2017, 114, E5995-E6004. [CrossRef]

66. Xue, T.; Dai, X.; Wang, R.; Wang, J.; Liu, Z.; Xiang, F. ARGONAUTE10 inhibits in vitro shoot regeneration via repression of miR165/166 in arabidopsis thaliana. Plant Cell Physiol. 2017, 58, 1789-1800. [CrossRef] [PubMed]

67. Yang, S.; Poretska, O.; Sieberer, T. ALTERED MERISTEM PROGRAM1 restricts shoot meristem proliferation and regeneration by limiting HD-ZIP III-mediated expression of RAP2.61. Plant Physiol. 2018, 177, 1580-1594. [CrossRef] [PubMed]

68. Shi, B.; Zhang, C.; Tian, C.; Wang, J.; Wang, Q.; Xu, T.; Xu, Y.; Ohno, C.; Sablowski, R.; Heisler, M.G.; et al. Two-Step Regulation of a Meristematic Cell Population Acting in Shoot Branching in Arabidopsis. PLoS Genet. 2016, 12, e1006168. [CrossRef] [PubMed]

69. Ma, Y.; Miotk, A.; Šutiković, Z.; Ermakova, O.; Wenzl, C.; Medzihradszky, A.; Gaillochet, C.; Forner, J.; Utan, G.; Brackmann, K.; et al. WUSCHEL acts as an auxin response rheostat to maintain apical stem cells in Arabidopsis. Nat. Commun. 2019, 10,1-11. [CrossRef] [PubMed]

70. Leibfried, A.; To, J.P.C.; Busch, W.; Stehling, S.; Kehle, A.; Demar, M.; Kieber, J.J.; Lohmann, J.U. WUSCHEL controls meristem function by direct regulation of cytokinin-inducible response regulators. Nature 2005, 438, 1172-1175. [CrossRef]

71. Negin, B.; Shemer, O.; Sorek, Y.; Eshed Williams, L. Shoot stem cell specification in roots by the WUSCHEL transcription factor. PLoS ONE 2017, 12, e0176093. [CrossRef]

72. Li, W.; Liu, H.; Cheng, Z.J.; Su, Y.H.; Han, H.N.; Zhang, Y.; Zhang, X.S. DNA Methylation and Histone Modifications Regulate De Novo Shoot Regeneration in Arabidopsis by Modulating WUSCHEL Expression and Auxin Signaling. PLoS Genet. 2011, 7, e1002243. [CrossRef]

73. Liu, H.; Zhang, H.; Dong, Y.X.; Hao, Y.J.; Zhang, X.S. DNA METHYLTRANSFERASE1-mediated shoot regeneration is regulated by cytokinin-induced cell cycle in Arabidopsis. New Phytol. 2017, 217, 219-232. [CrossRef]

74. Zhang, T.-Q.; Lian, H.; Tang, H.; Dolezal, K.; Zhou, C.-M.; Yu, S.; Chen, J.-H.; Chen, Q.; Liu, H.; Ljung, K.; et al. An intrinsic microRNA timer regulates progressive decline in shoot regenerative capacity in plants. Plant Cell 2015, 27, 349-360. [CrossRef]

75. Gordon, S.P.; Chickarmane, V.S.; Ohno, C.; Meyerowitz, E.M. Multiple feedback loops through cytokinin signaling control stem cell number within the Arabidopsis shoot meristem. Proc. Natl. Acad. Sci. USA 2009, 106, 16529-16534. [CrossRef]

76. Perales, M.; Reddy, G.V. Stem cell maintenance in shoot apical meristems. Curr. Opin. Plant Biol. 2012, 15, 10-16. [CrossRef] [PubMed]

77. Matsuo, N.; Banno, H. Arabidopsis ENHANCER OF SHOOT REGENERATION 2 and PINOID are involved in in vitro shoot regeneration. Plant Biotechnol. 2012, 29, 367-372. [CrossRef]

78. Reinhardt, D.; Pesce, E.R.; Stieger, P.; Mandel, T.; Baltensperger, K.; Bennett, M.; Traas, J.; Friml, J.; Kuhlemeier, C. Regulation of phyllotaxis by polar auxin transport. Nature 2003, 426, 255-260. [CrossRef]

79. Lee, K.; Park, O.S.; Choi, C.Y.; Seo, P.J. ARABIDOPSIS TRITHORAX 4 Facilitates Shoot Identity Establishment during the Plant Regeneration Process. Plant Cell Physiol. 2019, 60, 826-834. [CrossRef] [PubMed]

80. Lardon, R.; Wijnker, E.; Keurentjes, J.; Geelen, D. The genetic framework of shoot regeneration in Arabidopsis comprises master regulators and conditional fine-tuning factors. Commsbio 2020, accepted. 
81. Motte, H.; Vercauteren, A.; Depuydt, S.; Landschoot, S.; Geelen, D.; Werbrouck, S.; Goormachtig, S.; Vuylsteke, M.; Vereecke, D. Combining linkage and association mapping identifies RECEPTOR-LIKE PROTEIN KINASE1 as an essential Arabidopsis shoot regeneration gene. Proc. Natl. Acad. Sci. USA 2014, 111, 8305-8310. [CrossRef]

82. Velázquez, I.; Valencia, S.; López-Lera, A.; de La Peña, A.; Candela, M. Analysis of natural allelic variation in in vitro organogenesis of Arabidopsis thaliana. Euphytica 2004, 137, 73-79. [CrossRef]

83. Schiantarelli, E.; De la Peña, A.; Candela, M. Use of recombinant inbred lines (RILs) to identify, locate and map major genes and quantitative trait loci involved with in vitro regeneration ability in Arabidopsis thaliana. Theor. Appl. Genet. 2001, 102, 335-341. [CrossRef]

84. Ozawa, S.; Yasutani, I.; Fukuda, H.; Komamine, A.; Sugiyama, M. Organogenic responses in tissue culture of srd mutants of Arabidopsis thaliana. Development 1998, 125, 135-142.

85. Lall, S.; Nettleton, D.; DeCook, R.; Che, P.; Howell, S.H. Quantitative trait loci associated with adventitious shoot formation in tissue culture and the program of shoot development in Arabidopsis. Genetics 2004, 167, 1883-1892. [CrossRef] [PubMed]

86. Nodine, M.D.; Yadegari, R.; Tax, F.E. RPK1 and TOAD2 Are Two Receptor-like Kinases Redundantly Required for Arabidopsis Embryonic Pattern Formation. Dev. Cell 2007, 12, 943-956. [CrossRef] [PubMed]

87. Nodine, M.D.; Tax, F.E. Two receptor-like kinases required together for the establishment of Arabidopsis cotyledon primordia. Dev. Biol. 2008, 314, 161-170. [CrossRef] [PubMed]

88. Luichtl, M.; Fiesselmann, B.S.; Matthes, M.; Yang, X.; Peis, O.; Brunner, A.; Torres-Ruiz, R.A. Mutations in the Arabidopsis RPK1 gene uncouple cotyledon anlagen and primordia by modulating epidermal cell shape and polarity. Biol. Open 2013, 2, 1093-1102. [CrossRef]

89. Kinoshita, A.; Betsuyaku, S.; Osakabe, Y.; Mizuno, S.; Nagawa, S.; Stahl, Y.; Simon, R.; Yamaguchi-Shinozaki, K.; Fukuda, H.; Sawa, S. RPK2 is an essential receptor-like kinase that transmits the CLV3 signal in Arabidopsis. Development 2010, 137, 3911-3920. [CrossRef]

90. Fiesselmann, B.S.; Luichtl, M.; Yang, X.; Matthes, M.; Peis, O.; Torres-Ruiz, R.A. Ectopic shoot meristem generation in monocotyledonous rpk1 mutants is linked to SAM loss and altered seedling morphology. BMC Plant Biol. 2015, 15, 171. [CrossRef]

91. Zhang, H.; Zhang, T.T.; Liu, H.; Shi, D.Y.; Wang, M.; Bie, X.M.; Li, X.G.; Zhang, X.S. Thioredoxin-mediated ROS homeostasis explains natural variation in plant regeneration. Plant Physiol. 2018, 176, 2231-2250. [CrossRef]

92. Marchadier, E.; Hanemian, M.; Tisné, S.; Bach, L.; Bazakos, C.; Gilbault, E.; Haddadi, P.; Virlouvet, L.; Loudet, $\mathrm{O}$. The complex genetic architecture of shoot growth natural variation in Arabidopsis thaliana. PLoS Genet. 2019, 15, 1-27. [CrossRef]

93. Taguchi-Shiobara, F.; Yamamoto, T.; Yano, M.; Oka, S. Mapping QTLs that control the performance of rice tissue culture and evaluation of derived near-isogenic lines. Theor. Appl. Genet. 2006, 112, 968-976. [CrossRef]

94. Li, S.; Yan, S.; Wang, A.; Zou, G.; Huang, X.; Han, B.; Qian, Q.; Tao, Y. Identification of QTLs associated with tissue culture response through sequencing-based genotyping of RILs derived from 93-11 $\times$ Nipponbare in rice (Oryza sativa). Plant Cell Rep. 2013, 32, 103-116. [CrossRef]

95. Taguchi-Shiobara, F.; Lin, S.Y.; Tanno, K.; Komatsuda, T.; Yano, M.; Sasaki, T.; Oka, S. Mapping quantitative trait loci associated with regeneration ability of seed callus in rice, Oryza sativa L. Theor. Appl. Genet. 1997, 95, 828-833. [CrossRef]

96. Takeuchi, Y.; Abe, T.; Sasahara, T. RFLP mapping of QTLs influencing shoot regeneration from mature seed-derived calli in rice. Crop. Sci. 2000, 40, 245-247. [CrossRef]

97. Kwon, Y.S.; Eun, M.Y.; Sohn, J.K. Marker-assisted selection for identification of plant regeneration ability of seed-derived calli in rice (Oryza sativa L.). Mol. Cells 2001, 12, 103-106.

98. Nishimura, A.; Ashikari, M.; Lin, S.; Takashi, T.; Angeles, E.R.; Yamamoto, T.; Matsuoka, M. Isolation of a rice regeneration quantitative trait loci gene and its application to transformation systems. Proc. Natl. Acad. Sci. USA 2005, 102, 11940-11944. [CrossRef] [PubMed]

99. Zhao, L.; Zhou, H.; Lu, L.; Liu, L.; Li, X.; Lin, Y.; Yu, S. Identification of quantitative trait loci controlling rice mature seed culturability using chromosomal segment substitution lines. Plant Cell Rep. 2009, 28, 247-256. [CrossRef] [PubMed] 
100. Tian, F.-K.; Ruan, B.-P.; Yan, M.X.; Ye, S.F.; Peng, Y.L.; Dong, G.J.; Zhu, L.; Hu, J.; Yan, H.L.; Guo, L.B.; et al. Genetic analysis and QT1 mapping of mature seed culturability in indica rice. Rice Sci. 2013, 20, 313-319. [CrossRef]

101. Bolibok, H.; Rakoczy-Trojanowska, M. Genetic mapping of QTLs for tissue-culture response in plants. Euphytica 2006, 149, 73-83. [CrossRef]

102. Zhang, Z.; Zhao, H.; Li, W.; Wu, J.; Zhou, Z.; Zhou, F.; Chen, H.; Lin, Y. Genome-wide association study of callus induction variation to explore the callus formation mechanism of rice. J. Integr. Plant Biol. 2019, 61, 1134-1150. [CrossRef] [PubMed]

103. Zhang, K.; Su, J.; Xu, M.; Zhou, Z.; Zhu, X.; Ma, X.; Hou, J.; Tan, L.; Zhu, Z.; Cai, H.; et al. A common wild rice-derived BOC1 allele reduces callus browning in indica rice transformation. Nat. Commun. 2020, 11. [CrossRef]

104. Armstrong, C.L.; Romero-Severson, J.; Hodges, T.K. Improved tissue culture response of an elite maize inbred through backcross breeding, and identification of chromosomal regions important for regeneration by RFLP analysis. Theor. Appl. Genet. 1992, 84, 755-762. [CrossRef]

105. Ma, L.; Liu, M.; Yan, Y.; Qing, C.; Zhang, X.; Zhang, Y.; Long, Y.; Wang, L.; Pan, L.; Zou, C.; et al. Genetic Dissection of Maize Embryonic Callus Regenerative Capacity Using Multi-Locus Genome-Wide Association Studies. Front. Plant Sci. 2018, 9. [CrossRef] [PubMed]

106. Salvo, S.; Cook, J.; Carlson, A.R.; Hirsch, C.N.; Kaeppler, S.M.; Kaeppler, H.F. Genetic Fine-Mapping of a Quantitative Trait Locus (QTL) Associated with Embryogenic Tissue Culture Response and Plant Regeneration Ability in Maize (Zea mays L.). Plant Genome 2018, 11, 170111. [CrossRef] [PubMed]

107. Ben Amer, I.M.; Korzun, V.; Worland, A.J.; Börner, A. Genetic mapping of QTL controlling tissue-culture response on chromosome $2 \mathrm{~B}$ of wheat (Triticum aestivum L.) in relation to major genes and RFLP markers. Theor. Appl. Genet. 1997, 94, 1047-1052. [CrossRef]

108. Jia, H.; Yi, D.; Yu, J.; Xue, S.; Xiang, Y.; Zhang, C.; Zhang, Z.; Zhang, L.; Ma, Z. Mapping QTLs for tissue culture response of mature wheat embryos. Mol. Cells 2007, 23, 323-330.

109. Ma, J.; Deng, M.; Lv, S.Y.; Yang, Q.; Jiang, Q.T.; Qi, P.F.; Li, W.; Chen, G.Y.; Lan, X.J.; Wei, Y.M. Identification of QTLs associated with tissue culture response of mature wheat embryos. Springerplus 2016, 5. [CrossRef]

110. Mano, Y.; Takahashi, H.; Sato, K.; Takeda, K. Mapping genes for callus growth and shoot regeneration in barley (Hordeum vulgare L.). Breed. Sci. 1996, 46, 137-142. [CrossRef]

111. Mano, Y.; Komatsuda, T. Identification of QTLs controlling tissue-culture traits in barley (Hordeum vulgare L.). Theor. Appl. Genet. 2002, 105, 708-715. [CrossRef]

112. Tyagi, N.; Dahleen, L.S.; Bregitzer, P. Candidate genes within tissue culture regeneration QTL revisited with a linkage map based on transcript-derived markers. Crop. Sci. 2010, 50, 1697-1707. [CrossRef]

113. Lowe, K.; Wu, E.; Wang, N.; Hoerster, G.; Hastings, C.; Cho, M.J.; Scelonge, C.; Lenderts, B.; Chamberlin, M.; Cushatt, J.; et al. Morphogenic regulators Baby boom and Wuschel improve monocot transformation. Plant Cell 2016, 28, 1998-2015. [CrossRef]

114. Nielsen, N.H.; Andersen, S.U.; Stougaard, J.; Jensen, A.; Backes, G.; Jahoor, A. Chromosomal regions associated with the in vitro culture response of wheat (Triticum aestivum L.) microspores. Plant Breed. 2015, 134, 255-263. [CrossRef]

115. Hisano, H.; Sato, K. Genomic regions responsible for amenability to Agrobacterium-mediated transformation in barley. Sci. Rep. 2016, 6, 1-11. [CrossRef] [PubMed]

116. Hisano, H.; Meints, B.; Moscou, M.J.; Cistue, L.; Echávarri, B.; Sato, K.; Hayes, P.M. Selection of transformation-efficient barley genotypes based on TFA (transformation amenability) haplotype and higher resolution mapping of the TFA loci. Plant Cell Rep. 2017, 36, 611-620. [CrossRef] [PubMed]

117. Koornneef, M.; Bade, J.; Hanhart, C.; Horsman, K.; Schel, J.; Soppe, W.; Verkerk, R.; Zabel, P. Characterization and mapping of a gene controlling shoot regeneration in tomato. Plant J. 1993, 3, 131-141. [CrossRef]

118. Satoh, H.; Takashina, T.; Escalante, A.; Egashira, H.; Imanishi, S. Molecular Markers Mapped around the High Shoot Regeneration Capacity Gene Rg-2 in Lycopersicon chilense. Breed. Sci. 2000, 50, 251-256. [CrossRef]

119. Trujillo-Moya, C.; Gisbert, C.; Vilanova, S.; Nuez, F. Localization of QTLs for in vitro plant regeneration in tomato. BMC Plant Biol. 2011, 11, 140. [CrossRef] [PubMed] 
120. Lombardi-Crestana, S.; da Silva Azevedo, M.; e Silva, G.F.F.; Pino, L.E.; Appezzato-da-Glória, B.; Figueira, A.; Nogueira, F.T.S.; Peres, L.E.P. The tomato (Solanum lycopersicum cv Micro-Tom) natural methylation and chromatin patterning genetic variation $\mathrm{Rg} 1$ and the DELLA mutant procera control the competence necessary to form adventitious roots and shoots. J. Exp. Bot. 2012, 63, 5689-5703. [CrossRef] [PubMed]

121. Wang, Y.; Zhou, Q.; Zhu, G.; Wang, S.; Ma, Y.; Miao, H.; Zhang, S.; Huang, S.; Zhang, Z.; Gu, X. Genetic analysis and identification of a candidate gene associated with in vitro regeneration ability of cucumber. Theor. Appl. Genet. 2018, 131, 2663-2675. [CrossRef]

122. Kim, K.; Kang, Y.; Lee, S.J.; Choi, S.H.; Jeon, D.H.; Park, M.Y.; Park, S.; Lim, Y.P.; Kim, C. Quantitative trait loci (QTLs) associated with microspore culture in Raphanus sativus L. (radish). Genes 2020, 11, 337. [CrossRef]

123. Holme, I.B.; Torp, A.M.; Hansen, L.N.; Andersen, S.B. Quantitative trait loci affecting plant regeneration from protoplasts of Brassica oleracea. Theor. Appl. Genet. 2004, 108, 1513-1520. [CrossRef]

124. Van Sint, J.; Laublin, G.; Birhman, R.K.; Cappadocia, M. Genetic analysis of leaf explant regenerability in Solanum chacoense. Plant Cell. Tissue Organ. Cult. 1996, 47, 9-13. [CrossRef]

125. Nguyen, T.H.N.; Schulz, D.; Winkelmann, T.; Debener, T. Genetic dissection of adventitious shoot regeneration in roses by employing genome-wide association studies. Plant Cell Rep. 2017, 36, 1493-1505. [CrossRef] [PubMed]

126. Flores Berrios, E.; Sarrafi, A.; Fabre, F.; Alibert, G.; Gentzbittel, L. Genotypic variation and chromosomal location of QTLs for somatic embryogenesis revealed by epidermal layers culture of recombinant inbred lines in the sunflower (Helianthus annuus L.). Theor. Appl. Genet. 2000, 101, 1307-1312. [CrossRef]

127. Flores Berrios, E.; Gentzbittel, L.; Kayyal, H.; Alibert, G.; Sarrafi, A. AFLP mapping of QTLS for in vitro organogenesis traits, using recombinant inbred lines in sunflower (Helianthus annuus L.). Theor. Appl. Genet. 2000, 101, 1299-1306. [CrossRef]

128. Tuskan, G.A.; Mewalal, R.; Gunter, L.E.; Palla, K.J.; Carter, K.; Jacobson, D.A.; Jones, P.C.; Garcia, B.J.; Weighill, D.A.; Hyatt, P.D.; et al. Defining the genetic components of callus formation: A GWAS approach. PLoS ONE 2018, 13, e0202519. [CrossRef]

129. Sun, P.; Jia, H.; Zhang, Y.; Li, J.; Lu, M.; Hu, J. Deciphering genetic architecture of adventitious root and related shoot traits in populus using qtl mapping and RNA-seq data. Int. J. Mol. Sci. 2019, 20, 6114. [CrossRef] [PubMed]

130. Lee, K.; Park, O.; Seo, P.J. RNA-Seq Analysis of the Arabidopsis Transcriptome in Pluripotent Calli. Mol. Cells 2016, 39, 484-494. [CrossRef]

131. Zhang, Y.Y.; Latzel, V.; Fischer, M.; Bossdorf, O. Understanding the evolutionary potential of epigenetic variation: A comparison of heritable phenotypic variation in epiRILs, RILs, and natural ecotypes of Arabidopsis thaliana. Heredity (Edinb) 2018, 121, 257-265. [CrossRef]

132. Schmid, M.W.; Heichinger, C.; Coman Schmid, D.; Guthörl, D.; Gagliardini, V.; Bruggmann, R.; Aluri, S.; Aquino, C.; Schmid, B.; Turnbull, L.A.; et al. Contribution of epigenetic variation to adaptation in Arabidopsis. Nat. Commun. 2018, 9. [CrossRef]

133. Becker, C.; Hagmann, J.; Müller, J.; Koenig, D.; Stegle, O.; Borgwardt, K.; Weigel, D. Spontaneous epigenetic variation in the Arabidopsis thaliana methylome. Nature 2011, 480, 245-249. [CrossRef]

134. Kawakatsu, T.; Huang, S.C.; Jupe, F.; Sasaki, E.; Schmitz, R.J.J.; Urich, M.A.A.; Castanon, R.; Nery, J.R.R.; Barragan, C.; He, Y.; et al. Epigenomic Diversity in a Global Collection of Arabidopsis thaliana Accessions. Cell 2016, 166, 492-505. [CrossRef]

135. Zhang, X.; Shiu, S.; Cal, A.; Borevitz, J.O. Global analysis of genetic, epigenetic and transcriptional polymorphisms in Arabidopsis thaliana using whole genome tiling arrays. PLoS Genet. 2008, 4. [CrossRef]

136. Vaughn, M.W.; Tanurdžić, M.; Lippman, Z.; Jiang, H.; Carrasquillo, R.; Rabinowicz, P.D.; Dedhia, N.; McCombie, W.R.; Agier, N.; Bulski, A.; et al. Epigenetic natural variation in Arabidopsis thaliana. PLoS Biol. 2007, 5, 1617-1629. [CrossRef] [PubMed]

137. Zhang, Y.; Wendte, J.M.; Ji, L.; Schmitz, R.J. Natural variation in DNA methylation homeostasis and the emergence of epialleles. Proc. Natl. Acad. Sci. USA 2020, 117, 4874-4884. [CrossRef] [PubMed]

138. Zhai, J.; Liu, J.; Liu, B.; Li, P.; Meyers, B.C.; Chen, X.; Cao, X. Small RNA-directed epigenetic natural variation in Arabidopsis thaliana. PLoS Genet. 2008, 4. [CrossRef] [PubMed]

139. Pignatta, D.; Erdmann, R.M.; Scheer, E.; Picard, C.L.; Bell, G.W.; Gehring, M. Natural epigenetic polymorphisms lead to intraspecific variation in Arabidopsis gene imprinting. Elife 2014, 3, 1-24. [CrossRef] [PubMed] 
140. Kooke, R.; Johannes, F.; Wardenaar, R.; Becker, F.; Etcheverry, M.; Colot, V.; Vreugdenhil, D.; Keurentjes, J.J.B. Epigenetic basis of morphological variation and phenotypic plasticity in Arabidopsis thaliana. Plant Cell 2015, 27, 337-348. [CrossRef] [PubMed]

141. Lang, Z.; Xie, S.; Zhu, J.K. The 1001 Arabidopsis DNA Methylomes: An Important Resource for Studying Natural Genetic, Epigenetic, and Phenotypic Variation. Trends Plant Sci. 2016, 21, 906-908. [CrossRef]

142. Dong, X.; Reimer, J.; Göbel, U.; Engelhorn, J.; He, F.; Schoof, H.; Turck, F. Natural variation of H3K27me3 distribution between two Arabidopsis accessions and its association with flanking transposable elements. Genome Biol. 2012, 13, R117. [CrossRef]

143. Candela, M.; Velázquez, I.; De la Cruz, B.; Sendino, A.M.; De la Peña, A. Differences in in vitro plant regeneration ability among four Arabidopsis thaliana ecotypes. Vitr. Cell. Dev. Biol. Plant. 2001, 37, 638-643. [CrossRef]

144. Zhang, X.; Hause, R.J.; Borevitz, J.O.; Borevitz, J.O. Natural Genetic Variation for Growth and Development Revealed by High-Throughput Phenotyping in Arabidopsis thaliana. G3 (Bethesda) 2012, 2, 29-34. [CrossRef]

145. Atwell, S.; Huang, Y.S.; Vilhjálmsson, B.J.; Willems, G.; Horton, M.; Li, Y.; Meng, D.; Platt, A.; Tarone, A.M.; $\mathrm{Hu}$, T.T.; et al. Genome-wide association study of 107 phenotypes in Arabidopsis thaliana inbred lines. Nature 2010, 465, 627-631. [CrossRef] [PubMed]

146. Cary, A.; Uttamchandani, S.J.; Smets, R.; Van Onckelen, H.A.; Howell, S.H. Arabidopsis mutants with increased organ regeneration in tissue culture are more competent to respond to hormonal signals. Planta 2001, 213, 700-707. [CrossRef] [PubMed]

147. Rasmussen, A.; Hosseini, S.A.; Hajirezaei, M.-R.; Druege, U.; Geelen, D. Adventitious rooting declines with the vegetative to reproductive switch and involves a changed auxin homeostasis. J. Exp. Bot. 2015, 66, 1437-1452. [CrossRef] [PubMed]

148. Lee, S.; Sergeeva, L.I.; Vreugdenhil, D. Natural variation of hormone levels in Arabidopsis roots and correlations with complex root architecture. J. Integr. Plant Biol. 2018, 60, 292-309. [CrossRef] [PubMed]

149. Chatfield, S.P.; Raizada, M.N. Ethylene and shoot regeneration: Hookless1 modulates de novo shoot organogenesis in Arabidopsis thaliana. Plant Cell Rep. 2008, 27, 655-666. [CrossRef] [PubMed]

150. Delker, C.; Pöschschl, Y.; Raschke, A.; Ullrich, K.; Ettingshausen, S.; Hauptmann, V.; Grosse, I.; Quint, M. Natural variation of transcriptional auxin response networks in Arabidopsis thaliana. Plant Cell 2010, 22, 2184-2200. [CrossRef]

151. Durgaprasad, K.; Roy, M.V.; Venugopal, A.; Kareem, A.; Raj, K.; Willemsen, V.; Mähönen, A.P.; Scheres, B.; Prasad, K. Gradient Expression of Transcription Factor Imposes a Boundary on Organ Regeneration Potential in Plants. Cell Rep. 2019, 29, 453-463.e3. [CrossRef]

152. Togninalli, M.; Seren, Ü.; Meng, D.; Fitz, J.; Nordborg, M.; Weigel, D.; Borgwardt, K.; Korte, A.; Grimm, D.G. The AraGWAS Catalog: A curated and standardized Arabidopsis thaliana GWAS catalog. Nucleic Acids Res. 2018, 46, D1150-D1156. [CrossRef]

153. Seren, Ü.; Grimm, D.; Fitz, J.; Weigel, D.; Nordborg, M.; Borgwardt, K.; Korte, A. AraPheno: A public database for Arabidopsis thaliana phenotypes. Nucleic Acids Res. 2017, 45, 1054-1059. [CrossRef]

154. Exposito-Alonso, M.; Exposito-Alonso, M.; Gómez Rodríguez, R.; Barragán, C.; Capovilla, G.; Chae, E.; Devos, J.; Dogan, E.S.; Friedemann, C.; Gross, C.; et al. Natural selection on the Arabidopsis thaliana genome in present and future climates. Nature 2019, 573, 126-129. [CrossRef]

155. Julkowska, M.M.; Koevoets, I.T.; Mol, S.; Hoefsloot, H.; Feron, R.; Tester, M.A.; Keurentjes, J.J.B.; Korte, A.; Haring, M.A.; De Boer, G.J.; et al. Genetic components of root architecture remodeling in response to salt stress. Plant Cell 2017, 29, 3198-3213. [CrossRef] [PubMed]

156. Strauch, R.C.; Svedin, E.; Dilkes, B.; Chapple, C.; Li, X. Discovery of a novel amino acid racemase through exploration of natural variation in Arabidopsis thaliana. Proc. Natl. Acad. Sci. USA 2015, 112, 11726-11731. [CrossRef] [PubMed]

157. Nameth, B.; Dinka, S.J.; Chatfield, S.P.; Morris, A.; English, J.; Lewis, D.; Oro, R.; Raizada, M.N. The shoot regeneration capacity of excised Arabidopsis cotyledons is established during the initial hours after injury and is modulated by a complex genetic network of light signalling. Plant Cell Environ. 2013, 36, 68-86. [CrossRef] [PubMed]

158. Negrutiu, I.; Jacobs, M. Factors which Enhance in vitro Morphogenesis of Arabidopsis thaliana. Z. Pflanzenphysiol. 1978, 90, 423-430. [CrossRef] 
159. Gupta, S.K.; Singh, P.K.; Sawant, S.V.; Chaturvedi, R.; Tuli, R. Effect of light intensity on in vitro multiple shoot induction and regeneration of cotton (Gossypium hirsutum L. cv Khandawa-2). Indian J. Exp. Biol. 2000, 38, 399-401.

160. Kwon, A.R.; Cui, H.Y.; Lee, H.; Shin, H.; Kang, K.S.; Park, S.Y. Light quality affects shoot regeneration, cell division, and wood formation in elite clones of Populus euramericana. Acta Physiol. Plant. 2015, 37, 1-9. [CrossRef]

161. Reuveni, M.; Evenor, D. On the effect of light on shoot regeneration in petunia. Plant Cell. Tissue Organ. Cult. 2007, 89, 49-54. [CrossRef]

162. Bhatia, P.; Ashwath, N. Effect of duration of light: Dark cycles on in vitro shoot regeneration of tomato. Asian J. Plant Sci. 2005, 3, 255-260.

163. Dimasi-Theriou, K.; Economou, A. Effect of Cold Temperature on Shoot Regeneration in Vitro from Aged Cultures of GF-677 (Prunus Persica $\times$ Prunus Amygdalus). In Plant Aging; Springer US: Boston, MA, USA, 1990; pp. 345-349.

164. Lee, S.-T.; Huang, W.-L. Osmotic stress stimulates shoot organogenesis in callus of rice (Oryza sativa L.) via auxin signaling and carbohydrate metabolism regulation. Plant Growth Regul. 2014, 73, 193-204. [CrossRef]

165. Wilson, M.E.; Mixdorf, M.; Berg, R.H.; Haswell, E.S. Plastid osmotic stress influences cell differentiation at the plant shoot apex. Development 2016, 143, 3382-3393. [CrossRef]

166. Piwowarczyk, B.; Kamińska, I.; Rybiński, W. Influence of PEG Generated Osmotic Stress on Shoot Regeneration and Some Biochemical Parameters in Lathyrus Culture. Orig. Pap. Czech. J. Genet. Plant Breed. 2014, 50, 2014-2077. [CrossRef]

167. Zhao, X.; Tan, H.J.; Liu, Y.B.; Li, X.R.; Chen, G.X. Effect of salt stress on growth and osmotic regulation in Thellungiella and Arabidopsis callus. Plant Cell. Tissue Organ. Cult. 2009, 98, 97-103. [CrossRef]

168. Gleddie, S. Plant regeneration from cell suspension cultures of Arabidopsis thaliana heynh. Plant Cell Rep. 1989, 8, 1-5. [CrossRef] [PubMed]

169. Dovzhenko, A.; Dal Bosco, C.; Meurer, J.; Koop, H.U. Efficient regeneration from cotyledon protoplasts in Arabidopsis thaliana. Protoplasma 2003, 222, 107-111. [CrossRef]

170. Scholl, R.L.; Keathley, D.E.; Baribault, T.J. Enhancement of Root Formation and Fertility in Shoots Regenerated From Anther- and Seedling-Derived Callus Cultures of Arabidopsis thaliana. Z. Pflanzenphysiol. 1981, 104, 225-231. [CrossRef]

171. Paulraj, S.; Yeung, E.C. Improved shoot regeneration from root explants using an abscisic acid-containing medium. In Methods in Molecular Biology; Humana Press Inc.: Totowa, NJ, USA, 2012; Volume 877, pp. 183-189, ISBN 9781617798177.

172. Gordon-Kamm, B.; Sardesai, N.; Arling, M.; Lowe, K.; Hoerster, G.; Betts, S.; Jones, T. Using Morphogenic Genes to Improve Recovery and Regeneration of Transgenic Plants. Plants 2019, 8, 38. [CrossRef]

173. Manske, U.; Landsmann, J.; Dietz-Pfeilstetter, A. Comparison of different methods for the establishment of RNA silencing in plants. Plant Biotechnol. Rep. 2017, 11, 115-125. [CrossRef]

174. Zhai, Z.; Sooksa-nguan, T.; Vatamaniuk, O.K. Establishing RNA interference as a reverse-genetic approach for gene functional analysis in protoplasts. Plant Physiol. 2009, 149, 642-652. [CrossRef]

175. Guo, H.S.; Fei, J.F.; Xie, Q.; Chua, N.H. A chemical-regulated inducible RNAi system in plants. Plant J. 2003, 34, 383-392. [CrossRef]

176. Fukudome, A.; Goldman, J.S.; Finlayson, S.A.; Koiwa, H. Silencing Arabidopsis CARBOXYL-TERMINAL DOMAIN PHOSPHATASE-LIKE 4 induces cytokinin-oversensitive de novo shoot organogenesis. Plant J. 2018, 94, 799-812. [CrossRef]

177. Hesami, M.; Naderi, R.; Tohidfar, M. Modeling and Optimizing Medium Composition for Shoot Regeneration of Chrysanthemum via Radial Basis Function-Non-dominated Sorting Genetic Algorithm-II (RBF-NSGAII). Sci. Rep. 2019, 9, 1-11. [CrossRef]

178. Hesami, M.; Condori-Apfata, J.A.; Valderrama Valencia, M.; Mohammadi, M. Application of Artificial Neural Network for Modeling and Studying In Vitro Genotype-Independent Shoot Regeneration in Wheat. Appl. Sci. 2020, 10, 5370. [CrossRef]

179. Hesami, M.; Naderi, R.; Tohidfar, M.; Yoosefzadeh-Najafabadi, M. Development of support vector machine-based model and comparative analysis with artificial neural network for modeling the plant tissue culture procedures: Effect of plant growth regulators on somatic embryogenesis of chrysanthemum, as a case study. Plant Methods 2020, 16, 112. [CrossRef] 
180. Kaur, P.; Gupta, R.C.; Dey, A.; Malik, T.; Pandey, D.K. Optimization of salicylic acid and chitosan treatment for bitter secoiridoid and xanthone glycosides production in shoot cultures of Swertia paniculata using response surface methodology and artificial neural network. BMC Plant Biol. 2020, 20, 225. [CrossRef]

181. García-Pérez, P.; Lozano-Milo, E.; Landín, M.; Gallego, P.P. Combining medicinal plant in vitro culture with machine learning technologies for maximizing the production of phenolic compounds. Antioxidants 2020, 9, 210. [CrossRef]

(C) 2020 by the authors. Licensee MDPI, Basel, Switzerland. This article is an open access article distributed under the terms and conditions of the Creative Commons Attribution (CC BY) license (http://creativecommons.org/licenses/by/4.0/). 